Article type : Original Article

\title{
Variation in style of magmatism and emplacement mechanism induced by changes in basin environments and stress fields (Pannonian Basin, Central Europe)
}

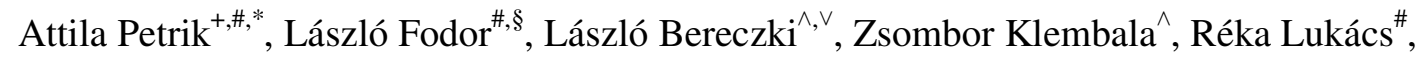 \\ Viktória Baranyi ${ }^{\mathbb{I l}}$, Barbara Beke ${ }^{\S}$ and Szabolcs Harangi, @
}

${ }^{+}$Department of Applied and Physical Geology, Eötvös University, Budapest, Hungary

${ }^{\#}$ MTA-ELTE Volcanology Research Group, Budapest, Hungary

*Department of Earth, Environmental and Resources Science, University of Naples Federico II, Naples, Italy

${ }^{\S}$ MTA-ELTE Geological, Geophysical and Space Science Research Group of the Hungarian Academy of Sciences, Ë̈tvös University, Budapest, Hungary

${ }^{\wedge}$ Department of Geophysics and Space Science, Eötvös University, Budapest, Hungary

${ }^{\vee}$ Mining and Geological Survey of Hungary, Budapest, Hungary

${ }^{I}$ Department of Geosciences, University of Oslo, Oslo, Norway

${ }^{\circledR}$ Department of Petrology and Geochemistry Eötvös University, Budapest, Hungary

*Correspondence, E-mail: petrik.atus@gmail.com, MTA-ELTE Volcanology Research Group, Eötvös University, Pázmány Péter sétány 1/C, 1117, Budapest, Hungary

\begin{abstract}
The development of high-resolution 3D seismic cubes has permitted recognition of variable subvolcanic features mostly located in passive continental margins. Our study area is situated in a different tectonic setting, in the extensional Pannonian Basin system (central Europe) where the lithospheric extension was associated with a wide variety of magmatic suites during the Miocene. Our primary objective is to map the buried magmatic bodies, to better understand the temporal and spatial variation in the style of magmatism and emplacement mechanism within the first order MidHungarian Fault Zone (MHFZ) along which substantial Miocene displacement took place. The combination of seismic, borehole and $\log$ data interpretation enabled us to delineate various previously unknown subvolcanic-volcanic features. In addition, a new approach of neural network This article has been accepted for publication and undergone full peer review but has not been through the copyediting, typesetting, pagination and proofreading process, which may lead to differences between this version and the Version of Record. Please cite this article as doi: $10.1111 /$ bre. 12326

This article is protected by copyright. All rights reserved.
\end{abstract}


analysis on log data was applied to detect and quantitatively characterise hydrothermal mounds that are hard to interpret solely from seismic data.

The volcanic activity started in the Middle Miocene and induced the development of extrusive volcanic mounds south of the NE-SW trending, continuous strike-slip fault zone (Hajdú Fault Zone). In the earliest Late Miocene (11.6-9.78 Ma), the style of magmatic activity changed resulting in emplacement of intrusions and development of hydrothermal mounds. Sill emplacement occurred from south-east to north-west based on primary flow-emplacement structures. The time of sill emplacement and the development of hydrothermal mounds can be bracketed by onlapped forced folds and mounds. This time coincided with the acceleration of sedimentation producing poorly consolidated, water-saturated sediments preventing magma from flowing to the paleosurface. The change in extensional direction resulted in change in fault pattern, thus the formerly continuous basinbounding strike-slip fault became segmented which could facilitate the magma flow toward the basin centre.

\section{INTRODUCTION}

With the advancement of 3D seismic cubes a great number of studies have been published on various subvolcanic features from well-studied different continental margins (Planke et al., 2005; Hansen \& Cartwright, 2006a; Lee et al., 2006; Holford et al., 2012; Jackson 2012; Jackson et al., 2013; Magee et al., 2013a, 2014; Zhao et al., 2016). Papers mainly focused on identifying and characterizing various intrusive and extrusive features and their implications on the evolution of sedimentary basins and petroleum systems (Planke et al., 2005; Lee et al., 2006; Holford et al., 2012, 2013; Klarner \& Klarner, 2012). The numerical and analogue modelling of volcanic intrusions and their emplacement mechanism has also been in the forefront of investigations for a long time (Pollard \& Johnson, 1973; Chevalier \& Woodford, 1999; Malthe-Sorenssen et al., 2004; Polteau et al., 2008). The lithological and structural control on sill emplacement mechanism have also been studied revealing their primarily role in the geometry and the movement mechanism of intrusions (Schofield et al., 2012a; Magee et al., 2013b; Walker, 2016; Eide et al., 2017a). More recent studies investigated the influence of fault geometry on the alignment of fluid escape structures (Magee et al., 2016). The spatial coincidence of forced folds overlying shallow-level saucer-shaped intrusions were linked to sill development (Hansen \& Cartwright, 2006a; Jackson et al., 2013; Magee et al., 2014). Forced folds onlapped by radiometrically or biostratigraphically dated formations have been successfully used to determine the time of magma emplacement (Hansen \& Cartwright, 2006a; Magee et al., 2014; Schofield et al., 2017a,b).

The majority of papers on volcanic intrusions have been published almost exclusively from rifted continental margins. In our study, we document sills, fluid-escape structures (e.g. hydrothermal mounds) and various volcanic edifices from a different tectonic setting, from the back-arc (Royden \& Horváth, 1988) or rift-related (Seghedi \& Downes, 2011) extensional Pannonian Basin system, from where some of the described features (e.g. hydrothermal mounds) have been not previously described.

This article is protected by copyright. All rights reserved. 
Our observations demonstrate a fossil case study on changes in style of magmatism from a localised, fault-controlled linear volcanic field to a basin-wide distribution of fault-guided intrusions and hydrothermal mounds. This change has been connected to several aspects of the evolution of the host sedimentary basin like sedimentation rate, sedimentation style and tectonic stress field. In this way, our observations contribute to better understanding the effects of changing basin environments on the style of magmatic activity. Since observations were made in the first order Mid-Hungarian Fault Zone (MHFZ) of the Pannonian Basin, along which substantial Miocene displacement took place, the recognised connected magmatic and structural features have implications for its tectonic evolution.

Our paper presents new methodological applications. Besides using conventional seismic interpretation methods, we also applied self-organizing neural networks based on selected seismic attributes to semi-automatically identify intrusions and cross-check our seismic interpretation. In addition, neural network facies analysis was used on available well-log, core samples and borehole data to recognise and quantitatively characterise hydrothermal mounds which generally pose great challenge in seismic interpretation. Such a semiautomatic method is poorly documented and our study may advance this research direction to be potentially implemented in other sedimentary basins.

\section{GEOLOGICAL SETTING AND STUDY AREA}

The Pannonian Basin is regarded as a back-arc (Royden et al., 1982; Royden \& Horváth, 1988; Horváth et al., 2015) or as a rift-related extensional basin (Seghedi \& Downes, 2011) with thin lithosphere and high heat flow values within the strongly arcuate Carpathian orogen. Lithospheric stretching started in the late Early Miocene and occurred due to the combined effects of gravitational collapse and eastward lateral movement of the AlCaPa block, formation of metamorphic core-complexes, slab roll back along the Carpathians and/or asthenospheric flow effect (Ratschbacher et al., 1989; Neubauer \& Genser, 1990; Tari et al., 1992; Horváth, 1993; Royden, 1993; Schmid et al., 2008; Kovács et al., 2012; Balázs et al., 2016).

The early syn-rift extension was associated with explosive eruptions of silicic magmas producing hundreds-of-meters thick pyroclastic deposits (Szabó et al., 1992; Seghedi et al., 2004; Pécskay et al., 2006; Harangi \& Lenkey, 2007; Lukács et al., 2015; 2018). They occur over an area of $\sim 100000 \mathrm{~km}^{2}$, but much of them are covered by $2-4 \mathrm{~km}$ thick Late Miocene to Quaternary sediments. Early and Mid-Miocene silicic and calc-alkaline volcanic activity of the Pannonian basin has been explained as mainly related to lithospheric extension (Lexa \& Konečný, 1974; Harangi, 2001; Harangi et al., 2001; Konečný et al., 2002; Seghedi et al., 2004; Harangi \& Lenkey, 2007; Seghedi \& Downes, 2011; Lukács et al., 2018). Primary magmas could have formed by decompression melting of the mantle lithosphere metasomatized by subduction-related fluids in the past.

The syn-rift sub-basins of the Pannonian Basin have combined extensional and strike-slip origin (Tari et al., 1992; Fodor et al., 1999; Horváth et al., 2015). During the late MidMiocene the uplift of the Alpine-Carpathian mountain belts, coupled with sea-level drop, resulted in the separation of the Pannonian Basin from the rest of the Central Paratethys (ter Borgh et al., 2013). This led to the birth of the Lake Pannon ( 11.6 Ma), a large isolated lake

This article is protected by copyright. All rights reserved. 
with a lifetime of 7 million years (Magyar et al., 1999, 2013). The formation of this lake was coeval with the onset of the post-rift thermal subsidence that was, however, timetransgressive and started earlier $(\sim 12 \mathrm{Ma})$ in the south-western and progressively later $(\sim 10-9$ Ma) in the north-eastern part of the basin (Horváth et al., 2015, Balázs et al., 2016). In parallel to the infilling of the lake, the Pannonian Basin was inverted from the Pliocene onward due to the plate reorganisations (Bada et al., 2007; Dombrádi et al., 2010).

The study area, a 3D seismic cube is located in the north-eastern part of the Pannonian Basin within the first-order Mid-Hungarian Fault Zone (MHFZ). This first-order shear zone separates two major terranes (Tisza-Dacia and AlCaPa: Alps-Carpathians-Pannonian) juxtaposed and dextrally displaced during the Early Miocene (Fig. 1) (Balla, 1984; Kázmér \& Kovács, 1985; Csontos et al., 1992; Fodor et al., 1998).

The study area is divided into two main parts based on their structures and morphology. The Polgár Trough (PT) is a 3-4 km deep NE-SW oriented half-graben filled with syn-rift marine to brackish claystone, siltstone and sandstone alternating with pyroclastic rocks as revealed by the Tiv-6 borehole (Figs 1B, 2, 3 and Supplementary Material, SM1: Tiv-6). The known oldest part of the syn-rift succession might be late Mid-Miocene (12.83-11.6 Ma) based on dynocysits which are organic skeletal microplanktons (SM1: Tiv-6). The earliest Late Miocene (11.6-9.78 Ma) part of the syn-rift suite started with marlstone and siltstone which represent deep lacustrine and shelf slope depositional environments of the Lake Pannon (Sztanó et al., 2013) (Figs 2, 3, SM1: Tiv-6). Above the $400-500 \mathrm{~m}$ thick pelitic, south-westward prograded slope sediments, the post-rift suite started with the deposition of deltaic and fluvial sediments during the Late Miocene (<9.78 Ma) (Figs 2, 3, SM1: Tiv-6, Tp1). It is capped by ca. 300-400m Plio-Quaternary fluvial sediments.

The southern border of the Polgár Trough is delineated by the NE-SW trending Hajdú Fault Zone (HF) including several segmented Late Miocene oblique-slip normal faults (H1-H5) (Fig. 1B). They seem to merge in depth into a single continuous fault at the level of Middle Miocene formations (Figs 1B, 3). One of the possible eastward continuations of the Hajdú Fault Zone is supposed to be the Bogdan-Voda Fault Zone (BVF) in the northern part of the Transylvanian Basin (Săndulescu, 1988; Ciulavu et al., 2002; Tischler et al., 2007). However, the exact fault pattern is concealed by the thick volcanic suites poorly imaged between the HF and Oaş-Gutâi Mts (Fig. 1A).

A NE-SW trending 25-30 km long, almost continuous buried volcanic zone (denoted here as Polgár Volcanic Field, PVF) is located south of the Polgár Trough. It includes different extrusive volcanic edifices located over positive $\Delta \mathrm{z}$ magnetic anomalies (Kiss \& Gulyás, 2006) (Figs 1B, 4A). Some boreholes (e.g. Tikeszi-1, HHE-Hn1) revealed that the volcanic edifices are composed of the alteration of rhyolite and andesite lava rocks with pyroclastics and Mid-Miocene siliciclastic deposits. Above the volcanic zone, the basinal and slope formations are often missing and the Upper Miocene is reduced to less than $1 \mathrm{~km}$ (Figs 2, 3, SM1: HGh-1). Another volcanic zone, called here as the Tiszakeszi Volcanic Field (TVF) is located in the south-western edge of the 3D seismic cube in the footwall block of the Hajdú Fault Zone (Figs 1B, 4A). It is made up of hundreds of meters thick pyroclastic and lava rocks (rhyolite and andesite) overlain by Late Miocene deltaic and fluvial sediments.

This article is protected by copyright. All rights reserved. 


\section{DATASET AND METHODOLOGY}

This study uses a post-stack time migrated, zero-phase 3D seismic reflection cube covering an area of $610 \mathrm{~km}^{2}$ (Fig. 1B). The inlines and crosslines are oriented NW-SE and NE-SW, respectively with a bin spacing of $25 \mathrm{~m}$. The data was displayed with normal polarity.

Calibration of seismic data to relevant geologic formations and calculation of interval velocities for packages of sedimentary strata were performed using check-shot data from Tikeszi-1 borehole and sonic log data from Tiv-6 and Tit-1 boreholes (SM2). All details of seismic data quality, interval velocity calculation are available in SM3. The presented but uninterpreted version of seismic profiles can be found in SM4 and SM5.

Extensive biostratigraphic data were used to constrain horizon ages down to the syn-rift packages (SM1: Tiv-6, Tp-1). Magnetostratigraphically calibrated horizons (Pogácsás et al., 1994) derived from the Tp-1 borehole constrained the basin evolution (SM1). Some K/Ar radiometric data from rhyolite and andesite were also available and gave 11.4 $\pm 0.7(\mathrm{Hn}-1)$ and

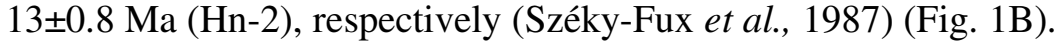

The log data of two boreholes (Tiv-6, HGh-1) have been investigated in more detail. They have various types of logs from which density (RHOB), gamma ray (GR) and photoelectric absorption (PE) were used to calibrate our seismic interpretation with rock information and to distinguish lithologies of sedimentary (GR:40-125 API, PE:1-4 b/e) and volcanic (GR:30-60 API, PE:3-4.5 b/e) rocks as well as fluid-escape structures (GR:20-30 API, PE:3.5-5.5 b/e). 5 horizons, including geological formation tops, magnetostratigraphically calibrated horizons and major unconformities were followed in the entire study area (Fig. 3). These horizons are (1-2) syn-rift-1 and -2, (3): base of Late Miocene sequence (blm, 11.6 Ma) often appearing as an unconformity surface; (4,5): reflections dividing the Late Miocene sequence into basinal, slope and deltaic/fluvial suites. Major faults have been also interpreted and correlated and fault-polygon maps were prepared for different horizons.

The subsidence curve and sedimentation rate for the Polgár Trough was taken from Petrik (2016) considering the paleontological and lithological data of the deepest borehole (Tiv-6) and the estimated sediment thickness maps for the late Mid-Miocene and Late Miocene (Magyar et al., 1999).

We mapped the volcanic/subvolcanic features using the seismostratigraphic approach of Planke et al. (2014). Time thickness (TWT) and numerous volumetric amplitude and timebased seismic attributes (e.g. coherency, Root Mean Square = RMS amplitude) were extracted along interpreted horizons or in a given time interval to map and enhance the volcanic/subvolcanic feature and related deformation pattern (e.g. forced folds). Volumetric RMS amplitude map along the base Late Miocene horizon delineated intrusions and extrusive volcanic edifices (Fig. 4B). Surface attribute maps were also used to display subvolcanicvolcanic features in 3D and to study flow emplacement structures (e.g. steps, bridges). Geometric (height, length, area) and volumetric properties of subvolcanic features were estimated by $3 \mathrm{D}$ voxelisation.

The magnetic $\Delta \mathrm{z}$ anomaly was used to check the spatial pattern of positive magnetic anomalies with respect to identified volcanic features. The details on the processing of this magnetic map are available in SM3.

This article is protected by copyright. All rights reserved. 
Self-organizing neural network analysis is widely used in seismic interpretation to map, among others, different seismic facies units (West et al., 2002; Saggaf et al., 2003; Baaske et al., 2007; Raeesi et al., 2012) and to mitigate the risks in hydrocarbon exploration (Malvić et al., 2010). Textural and neural networks have been successfully applied to identify volcanic rocks and volcanic facies units (West et al., 2002; Zhao et al., 2015), hence these methods seem to be plausible also in recognition and separation of different subvolcanic structures. We used various frequency-, (isofrequency, instantaneous frequency) and amplitude-based volumetric seismic attributes (e.g. reflection strength, RMS amplitude, sweetness) as inputs for clusterisation of neurons to determine different groups having similar seismic properties. Reflection strength and RMS amplitude are independent of phase and seismic polarity and highlights acoustically strong events (Brown, 2004). Sweetness is calculated as the instantaneous amplitude divided by the square-root of instantaneous frequency and used for detecting high amplitude and low frequency anomalies (Radovich \& Oliveros, 1998; Hart, 2008). Frequency attributes are suitable to identify seismic signal variation depending on frequency bands (Bacon et al., 2007). Seismic interpretation and self-organizing neural network analysis were performed using the IHS Kingdom and the Petrel 2012 software, respectively.

A neural network facies analysis was carried out on log data to identify and characterize various facies and lithological units through self-teaching procedures of neurons. The best discriminative log data (photoelectric absorption, gamma ray and density) from core samples interval were used to teach neurons for delineation of facies units in a semi-automatic way. The different classes of the neural net were constrained by the description of core samples and masterlogs (HGh-1). Cross-plots of GR/PE were made to demonstrate the identified various facies units having similar petrophysical properties. The identified facies units were tied to core sample descriptions and seismic interpretation. The trained neural network derived from the log data of HGh-1 was tested on another borehole (Tiv-6) where seismic interpretation indicated similar reflection packages. In this way, we were able to verify our seismic interpretation and the usability of the trained neural network. Neural network facies analysis was implemented by means of Techlog and Petrel software.

\section{DISTRIBUTION AND GEOMETRY OF VOLCANIC AND SUBVOLCANIC FEATURES}

\subsection{INTRUSIONS}

The 3-4 km deep central part of the Polgár Trough hosts various magmatic intrusions $(\mathrm{n}=28$, s1-s28) which align in a roughly NE-SW trending zone (Figs 4A,B). They are located between $2-3 \mathrm{sec}(\sim 3-4 \mathrm{~km}, \mathrm{v}=2600 \mathrm{~m} / \mathrm{s})$ from the surface and a few hundred metres $(100$ $1000 \mathrm{~m}$ ) under the former paleosurface horizon, which represents the surface at the time of intrusion emplacement. Their thickness changes between $50-120 \mathrm{~m}$ but only those were recognised whose size exceed the vertical resolution limit of 50-60 $\mathrm{m}(\lambda / 4)$; hence the number of intrusions may be significantly larger. Sills are generally displayed with their tuned thickness, but in case of some large shallow-level intrusions (e.g. sill 13, 14) the bottom and upper reflection can also be resolved. Schofield et al. (2017) demonstrated that ca. $88 \%$ of all

This article is protected by copyright. All rights reserved. 
the intrusions were below the vertical resolution of seismic data $(<40 \mathrm{~m})$ at depth of intrusion emplacement despite the high-quality and reprocessed 3D seismic data of the Faroe-Shetland Basin. Mark et al. (2018) also revealed that the majority of intrusion is seismically unresolvable and numerous thin intrusions $(<1 \mathrm{~m})$ cannot be detected even in wireline or cuttings data.

The mean surface area is $\sim 3 \mathrm{~km}^{2}$, ranging from $\sim 1$ to $10 \mathrm{~km}^{2}$ (s10, s11). The average volume of intrusions is $\sim 0.2-0.3 \mathrm{~km}^{3}$, while the cumulative volume might be $\sim 8-10 \mathrm{~km}^{3}$ but it is a rough overestimate taking the thickness of intrusions constant.

The interval RMS amplitude map around the base Late Miocene horizon (+/- $250 \mathrm{msec})$ clearly enhances the shape and distribution of interpreted intrusions; they have high RMS amplitude values $(>10000)$ with respect to the host rock $(<1000)$ of sandstone and siltstone (Fig. 4B). Intrusions have various shapes in map view, but the circular and elongated patterns prevail (Figs 4A,B).

Self-organising neural network analysis defined seismic bodies characterised by high RMS, Envelope and Sweetness, even tenfold reflection intensity and amplitude contrast with respect to host rocks and low iso-frequency component. They were spatially coincident with interpreted intrusions (SM6). The majority of sills are located in 2-2.8 sec (TWT) in the Polgár Trough and they have various shapes in 3D (e.g. saucer-shaped: sill18, layer-parallel: sill11) and some of them segmented by long linear features (e.g. s11, s12, s14) (SM6).

Intrusions have been interpreted as sills because: 1) they have the highest abruptly terminating positive amplitude in the syn-rift suite; 2) their geometry (e.g. saucer-shaped, layer-parallel) resembles those identified in passive continental margins (Thomson \& Hutton, 2004; Planke et al., 2005; Hansen \& Cartwright, 2006a; Magee et al., 2014); 3) they are often segmented, amalgamated or branched laterally and vertically (compound sills); 4) they are commonly overlain by forced folds; 5) they can often terminate under positive volcanic mounds and 6) they have well-characterised, distinct seismic properties revealed by neural network analysis. Following the identified sill facies units of Planke et al. (2005), six types of sills have been delineated based on their geometry, their connections with other volcanic structures and resulted deformation patterns.

\subsubsection{Slightly saucer-shaped sills}

When transgressive segments of sills are small and the layer-parallel geometry is dominant, we called sills as slightly saucer-shaped after Planke et al. (2005). Seven out of the 28 sills (s12-s17, s25) belong to this class and they are all located in the middle part of the Polgár Trough (Figs 4A,B). Although, saucer-shaped sills have generally sub-circular in plan view, the mapped slightly saucer shaped sills have elongated shape with predominantly NE-SW trending main axes. They are all found in shallow depth with a few hundred meters $(\sim 100-$ $500 \mathrm{~m}$ ) under the earliest Late Miocene paleosurface (ps) (Fig. 5A/1,3; 6: s13-s14). Some of them (s12, s14) are segmented which may be related to primary flow emplacement structures (e.g. steps) because segmentations do not coincide with underlying fault planes (Fig. 6: s14). In case of the s13, transgressive segments are developed at the edge of overlapping intrusions causing a step-like geometry ('bridge') (Fig. 5A/l).

This article is protected by copyright. All rights reserved. 
The largest amplitude (ff1: 120 m) forced fold can be observed above the segmented saucershaped sills (s13) whose thickness is approximately equal to the amplitude of the forced fold (ff1) (Figs 5A/1; 6, 7A,B). The lack of clear evidence to onlap of younger strata on forced fold (ff1) and the diverging geometry of overlying earliest Late Miocene deposits indicate compactional fold (Figs 7A,B,C,D). The difference in sediment thickness above the s13 can be observed under the shelf-slope progradation unit and progressively diminishes in the overlying strata (Figs 7A, B). In contrast, forced fold above the s17 is onlapped by earliest Late Miocene strata (11.6-9.78 Ma) (Fig. 5A/3). Interestingly, no forced folds were identified above the very shallowly $(50-100 \mathrm{~m}$ ) emplaced sills or lava flow (Fig. 8: $s 15-16$ ).

It should be also noted that seismically resolvable faults were not common in the forced folds, whereas some layer-bounded small-scale faults were identified below intrusions (Fig. 6).

\subsubsection{Layer-parallel sills}

Twelve out of the 28 sills have layer-parallel geometry and they are equally distributed within the NE-SW trending zone of the Polgár Trough (Figs 4A, B). The vast majority of them are located 100-600 $\mathrm{m}$ below the earliest Late Miocene paleosurface ( $\mathrm{ps}$ on Fig. 6). Segmentations are typical in this group and some of them are displayed as clear offsets ('steps') along the same intrusion (Figs 5A/2,6; 6: s11). The segmentations appear as roughly NW-SE trending long linear structures (SM6: s11, Fig. 9: s11, s23). In our interpretation, the segments are primary flow emplacement structures because host rocks around segmented intrusions are generally not displaced by faults. The linear features on RMS amplitude map of the s11 and s23 show branching geometry (Fig. 9) which was interpreted elsewhere as separate magma lobes of the propagating intrusion (Hansen \& Cartwright, 2006b; Magee et al., 2014).

Only one forced-fold was identified above layer-parallel sills of s8 and s9 (Fig. 5A/5). These sills are slightly tilted; run parallel and have an ' $\mathrm{F}$ '-shaped or ' $\mathrm{B}$ '-type junction (after Hansen et al., 2004) (Fig. 5A/5). The compactional forced fold above them follow the shape of the sills underneath; hence the largest thickness of the overlying strata can be observed in the dip direction of the tilted sills.

\subsubsection{Layer-parallel rough sills}

One compound sill (s24) consists of several roughly layer-parallel interconnected sills (Figs 4A, B, 5A/11). Sills run on different stratigraphic levels in the syn-rift suite and they are connected through ' $F$ '-shaped or 'B' type junctions (after Hansen et al., 2004). The host rock strata can also be deformed and bent between overlapping intrusions forming a bridge-like structure (Fig. 5A/11).

This article is protected by copyright. All rights reserved. 


\subsubsection{Climbing saucer-shaped sills}

Two of the smallest sills (s5, s10) (Figs 4A, B, 6: s5) have an asymmetric shape; one limb is short, whereas the other one is longer and has a gentle slope (Fig. 5A/4, Fig. 6: s5). They are intermediate stage between saucer-shaped and planar transgressive sills. The s5 is located $\sim 800 \mathrm{~m}$ from the paleosurface and terminates against a normal fault (Fig. 6). Forced fold cannot be detected above it. The s10 is situated much closer to the paleosurface ( 100-200 m) and it has a 'B'- type junction (after Hansen et al., 2004) with the underlying sill 1 (Fig. 5A/4). These sills are overlain by a compactional forced fold with the highest amplitude (120m) just above the junction point. The development of forced fold can be related to 1) vertical stacking of intrusions (multiple level intrusions) and 2) their vicinity to the paleosurface which might have exerted larger uplift of encasing strata.

\subsubsection{Planar transgressive sills}

Two sills (s20, s27) have discordant contact with the host rock and transgress a few hundred metres of sediments (Figs 4A,B). The s20 connects two layer-parallel sills with different types of junction (Fig. 5A/8). The upward termination of the s20 is a typical ' $\mathrm{C}$ ' type junction (after Hansen et al., 2004) with kink geometry and abrupt change in dip direction, whereas its downward termination is a ' $\mathrm{B}$ ' type junction with abutment against a layer-parallel sill (Fig. $5 \mathrm{~A} / 8)$. The s27 intersects even the base Late Miocene horizon which is a further proof of earliest Late Miocene emplacement of intrusion (Fig. 5A/7).

\subsubsection{Fault-related sills}

The geometry of four sills (s7, s18, s21, s22) was directly influenced by fault activity and the geometry of fault planes (Figs 4A,B). The s21 is an excellent example of how sills could use Mid-Miocene fault planes to move upward and then flow parallel to a discontinuity surface (e.g. bedding plane) (Figs 5A/9; 6). The s18 also used a Mid-Miocene fault plane at its termination (Fig. 6). The onlapped forced fold $(\sim 100-120 \mathrm{~m})$ over the s18 indicates earliest Late Miocene ( 11.6-9.78 Ma) sill emplacement. In contrast, the s22 sill terminates against a fault plane likely explained by the juxtaposition of two mechanically different lithologies across the fault (Fig. 5A/10).

\subsection{HYDROTHERMAL MOUNDS}

Altogether thirteen crater-hosted mounds have been detected at $\sim 1.5-2 \sec (\sim 2-2.5 \mathrm{~km})$ depth in the 3D seismic block; ten are located in the central and eastern part of the Polgár Trough and the remaining three in the NE-SW trending Polgár Volcanic Field (hm1-13, Fig. 4A). They can usually be found separately as single mounds but double mounds (Fig. 5B/14) and a NE-SW trending chain of 5 mounds were also revealed (hm2-hm6, Figs 4A, 8). The mounds have elongated $(70 \%)$ or circular $(30 \%)$ shape in map view (Fig. 4). They all have slightly eye-shaped geometry defining craters at their base which truncate underlying reflections on seismic profiles (Figs 5B/12-15; 6, 8). Their mean area is $\sim 2 \mathrm{~km}^{2}$; ranging from $1 \mathrm{~km}^{2}(\mathrm{hm} 2)$ to $\sim 3-3.5 \mathrm{~km}^{2}$ (hm11). Their amplitude (crater depth + mound height) ranges from $\sim 100 \mathrm{~m}$ to

This article is protected by copyright. All rights reserved. 
$\sim 400 \mathrm{~m}$ with the average of $\sim 150 \mathrm{~m}$. The volume of the crater-hosted mounds ranges from $0.03 \mathrm{~km}^{3}$ to $0.27 \mathrm{~km}^{3}$ with an average of $0.1 \mathrm{~km}^{3}$.

The crater-hosted mounds have strong positive amplitude upper and lower reflection boundaries but their internal seismic facies often consists of low-frequency, chaotic reflection packages (Figs 5B/12-15; 6, 8). All of them have erosive base with different crater depth $(\sim 60-250 \mathrm{~m})$ crosscutting host rock strata. Four mounds (hm2, hm3, hm12, hm13) have internal reflections downlapping onto the crater base horizon (Fig. 5B/14) consistent with progressive mound growth (Magee et al., 2013b). Neither resolvable subvertical, linear zones of seismic disturbance nor velocity pull-up features are observed below these mounds.

They are nested above fault tips (Figs 5B/13-14; 8), sill terminations (Figs 5B/12;6) or the combination of them (Fig. 5B/15); this strong spatial coincidence can suggest links between faults, mounds and sills. In case of the hm11, the compactional fault slightly dissects the mound and overlap with a large basin-bounding fault downward (Figs 5B/13).

The crater-hosted mounds are aligned close to the base Late Miocene horizon (blm), which in some cases constitutes their upper envelope surface. They are onlapped by earliest Late Miocene sediments ( 11.6-9.78 Ma). They are all overlain by compactional forced folds (amplitude: 80-120 m), which evolved in the overlying earliest Late Miocene mud-rich basinal facies unit. (Figs 6, 8).

The HGh-1 borehole penetrated one of the crater-hosted mounds (hm11) in the Polgár Volcanic Field (Figs 1B, SM1). Core analyses revealed $\sim 40 \mathrm{~m}$ thick ( 1210-1250 m), coarsegrained, matrix supported andesite hyaloclastite breccia with propilitic (chlorite-calcite) alteration. This contains many nests, veinlets and brecciated zones with fractures filled with Mg-rich calcite and well-crystallized zeolite minerals (e.g. heulandite, mordenite). This was interpreted as hydrothermal brecciation by Földessy \& Kupi (2009).

The crater-hosted mounds have been interpreted as fluid-escape structures (hydrothermal mounds) based on the following observations: 1) the geometry and size of features and their internal seismic facies correspond to those recognised and interpreted as hydrothermal mounds in passive continental margins (Planke et al., 2005; Lee et al., 2006; Magee et al., 2016); 2) they have erosive crater base indicating fluid explosion where expelled material contributed to the mound construction as observed in case of fluid-escape structures in NW Australia (Magee et al., 2016); 3) they are aligned along the former paleosurface and overlain by compactional forced folds; 4) they are onlapped by earliest Late Miocene strata consistent with the time of the emplacement of intrusions; 5) they always overlie fault tips and/or sill terminations; these features either guided or even triggered fluid expulsion; 6) they have chaotic internal reflection and strong upper and lower boundaries; 6) they have similar internal velocities than those of encasing strata; 7) there are no velocity pull-up features as opposed to other extrusive volcanic structures; 8) the HGh-1 borehole revealed hydrothermal breccia zone with zeolites and calcite which are common minerals in hydrothermally altered volcanic rocks (Kitsopoulos, 1997; Gifkins \& Allen, 2001; Marantos et al., 2011). Nevertheless, these zeolite minerals can form as a result of diagenetic alteration, but the spatial relationship between mounds and underlying sill and fault tips and the same formation time of mounds with emplacement of intrusions and finally the identified hydrothermal breccia zone in HGh-1 all suggest the hydrothermal origin of these mounds.

This article is protected by copyright. All rights reserved. 
Neural network facies analysis based on density (RHOB), gamma-ray (GR) and photoelectric absorption (PE) data of the HGh-1 borehole revealed semi-automatically four facies units having different petrophysical properties (Fig. 10A). One of the facies units has the highest $\mathrm{PE}$ and lowest GR values with high density which corresponds perfectly to the hydrothermal mound identified on seismic profiles and by core analysis (hm 11, Figs 5B/13; 10A). This facies unit is clearly distinct from the siliciclastic and volcanic rocks based on the crossplot of GR/PE values (Fig. 10A). The PE values of hydrothermal mounds are similar to those of calcite, anhydrite, and gypsum which are typical mineral associations in fluid-escape structures such as black or white-smokers (Tivey, 2016).

The combined seismic interpretation and trained neural network analysis was also successful in case of the Tiv- 6 borehole. The seismic interpretation indicates a crater-hosted mound with eye-shaped geometry with strong amplitude upper and lower boundary reflections (hm7, 2230-2300m) (Fig. 6). The mound has similar petrophysical attributes as that of the brecciated part of the HGh-1 (high PE and the lowest GR, Fig. 10B). The core analysis describes strongly altered tuffaceous sandstone with alkaline zeolite minerals and calcite alternating with marls and siltstones which can be the expression of hydrothermal mound.

\subsection{SUB-AERIAL VOLCANIC MOUNDS}

In the broader study area, three main, continuous volcanic fields (Polgár: PVF, Sajóhídvég: SVF and Tiszakeszi: TVF) and one small, slightly separated mound (Fig. 5C/19) close to the Tit-1 borhole were identified (Fig. 4A).

The area of continuous volcanic fields changes from $40 \mathrm{~km}^{2}$ (TVF) to $100 \mathrm{~km}^{2}$ (SVF, PVF) (Fig. 4A). They are composed of extrusive volcanic edifices like cones and domes. The height of mounds varies from 300 to $800 \mathrm{~m}$ with an average of 500-600 $\mathrm{m}$ and the average volcanic volume ranges from $6 \mathrm{~km}^{3}$ to $22 \mathrm{~km}^{3}$

Mounds have low-frequency, chaotic seismic facies (Fig. 5C/16-19), but in some cases reflections downlapping onto the base horizon also occur (Fig. 5C/16-18). The latter can be interpreted as sign for progressive mound growth after Magee et al. (2013b). Mounds are underlain by velocity pull-up features which might indicate high density volcanic rocks beneath the edifices (Fig. 5C/17-19).

Mounds are often associated with compactional faults accommodating the differential subsidence in the overlying strata (Fig. 5C/17-18). In some cases, mounds are dissected by small-scale layer-bounded faults (Fig. 5C/16).

The upper envelope surface of the mounds is displayed as a strong positive reflector. Mounds are onlapped by early Late Miocene strata (Fig. 5C/16-19), although a noticeable hiatus can be suspected, because the oldest basinal and slope facies is commonly missing over the mounds (SM1, HGh-1).

All mounds have positive $\Delta \mathrm{z}$ magnetic anomaly (Fig. 4A). Magnetic anomalies have longwavelength and small amplitude (20-40 nT) whose source regions are located between 2.2 and $11.2 \mathrm{~km}$ depth (Kiss, 2013, 2016). The shallower source was related to the widespread presence of Miocene volcanic rocks and their possible centres while the deeper source region was tied to large deformation zones along which magma sources were captured (Kiss, 2013, 2016).

This article is protected by copyright. All rights reserved. 
These features are interpreted as volcanic mounds including lava domes, small stratovolcanoes, volcanic cones based on the following observations: 1) their geometry (e.g. cone-shaped, dome-shaped) and their parameters, 2) they are larger than average hydrothermal mounds described in this area and in passive continental margins, 3) they have strong positive amplitude upper boundary surface and chaotic, noisy internal reflection packages, 4) velocity pull-up is commonly observed under them, 5) boreholes revealed hundreds-of-metres of pyroclastic and lavas, 6) mounds have positive $\Delta \mathrm{z}$ magnetic anomaly with source regions corresponding to volcanic centres, 7) their age is consistent with that of hydrothermal mounds and sills.

Details of uncertainties and difficulties in seismic interpretation related to seismic data quality and resolution/detection are available in SM7.

\section{DISCUSSION}

\subsection{SILLS AND MOUNDS}

Twenty eight sills have been recognised in the $\sim 5 \mathrm{~km}$ wide and $\sim 40 \mathrm{~km}$ long, NE-SW trending zone in the Polgár Trough, north of the basin-bounding Hajdú Fault (Figs 4A,B). Different markers indicate that intrusion depth was shallow, only 100-800 $\mathrm{m}$ from the coeval earliest Late Miocene paleosurface. The seismic facies of sills is characterized by high RMS, Envelope, Sweetness, reflection intensity and amplitude contrast with respect to host rocks and low iso-frequency component (SM6). Six different sill facies units have been defined based on their geometry following the classification of Planke et al. (2005). We did not identify clear a trend between sill facies units and emplacement depth as opposed to former observations from continental margins (Planke et al., 2005; Magee et al., 2014). The difference in confining pressure and temperature might have been negligible in case of very shallowly emplaced sills; hence the type of sill facies units was mainly influenced by the diverse lithology of the encasing strata. In addition, the magma emplacement rate, emplacement duration and physical properties of the magma might have also been important in case of very shallowly emplaced intrusions as emphasised by Reynolds et al. (2017).

Thirteen fluid-escape structures (hydrothermal mounds) were interpreted (Fig. 4A). They are all located along the earliest Late Miocene paleosurface. The geometrical properties of hydrothermal mounds (e.g. total height, area, average volume) are comparable to other offshore examples (Planke et al., 2005; Magee et al., 2016). Hydrothermal mounds occur over sill terminations and/or fault tips: this character is similar to those examples observed in rifted margins (Planke et al., 2005; Holford et al., 2012). In several cases, hydrothermal flows leading to mound formation were guided by faults or spatially connected to faults (Magee $e t$ al., 2016). The Pannonian examples clearly document such connections, while the NE-SW trending chain of hydrothermal mounds (hm2-hm6) occurs above Mid-Miocene splay faults (Fig. 8).

This article is protected by copyright. All rights reserved. 
In published examples, intrusions could also be essential to the initiation of fluid-escape structures; they heated up the encasing unconsolidated, highly water-saturated sediments, increased the fluid pressure, which initiated upward fluid migration along weakness zones (Jamtveit et al., 2004; Planke et al., 2005; Hansen et al., 2005; Svensen et al., 2006; Roberts et al., 2011). In summary, in the study area the combined effect of intrusions and the presence of active or inherited faults together, were the necessary conditions for hydrothermal mound formation. Repeated hydrothermal activity was revealed in the neighbouring southern TokajSlanské Mts in the similar early Late Miocene time, where it was connected to different magmatic centres and subvolcanic intrusions (Pécskay \& Molnár, 2002).

The important result of our study is to demonstrate the presence of hydrothermal mounds with independent data sets and methods. The usage of neural network facies analysis on log data (RHOZ, PE, GR) demonstrated that hydrothermal mounds have specific petrophysical signals which are clearly distinct (lowest GR and highest PE values) from other identified facies units (Fig. 10). In addition to well geophysical data, in one case (HGh-1), the hydrothermal mounds was penetrated and sampled by cores. The hydrothermal breccia zone with zeolite minerals (e.g. heulandite, mordenite) and calcite supports a hydrothermal mound origin.

Our examples and combined methodology for detection of hydrothermal mounds lay the ground for future seismic analyses and classifications.

\subsection{FORCED FOLDS AND THE TIME OF INTRUSION EMPLACEMENT}

Shallowly-emplaced $(<1.5 \mathrm{~km})$ saucer-shaped sills are commonly overlain by folded strata of the host rock (Koch et al., 1981; Cosgrove \& Hillier, 1999; Jackson et al., 2013; Magee et al., 2014). The genetic relationship between such forced folds and the evolution of underlying saucer-shaped intrusions have been explained by two different intrusion-induced uplift mechanisms (Hansen \& Cartwright, 2006a).

Those intrusions (e.g. s13-s14), which generated forced folds in the overlying strata, are mainly concentrated in the central part of the Polgár Trough (Fig. 7C). Here sediment thickness was slightly reduced with respect to areas devoid of intrusions but still remain much higher than that above the southern volcanic edifices. Both formation mechanisms of forced folds were recognised in the Polgár Trough. The largest forced folds $(\sim 100-120 \mathrm{~m}$ amplitude) were identified exclusively above shallowly-emplaced saucer-shaped sills (100$500 \mathrm{~m}$ from the paleosurface) (Figs 6, 7).

However, forced folds could not be observed above all shallowly-emplaced intrusions, which are especially true for layer-parallel sills (e.g. s11, Fig. 6). In the latter case, the reason for lacking deformed strata might be explained by mechanical layering of the host rock lithology (tuffaceous sandstone, siltstone, and claystone) and cementation level, as emphasized by Walker (2016) and Eide et al. (2017a). The lithology of encasing host rocks is both vertically and laterally heterogeneous. Jackson et al. (2013) pointed out that unconsolidated porous sediments with high fluid content are capable of hosting magma intrusion without elevating the overlying host rocks. Cementation processes and related drop in pore-space volume and increase in overall mechanical strength of encasing strata were emphasised as major factors

This article is protected by copyright. All rights reserved. 
influencing brittle or non-brittle mechanisms in magma emplacement (Schofield et al., 2012a).

Forced folds onlapped by the earliest Late Miocene strata ( 11.6-9.8 Ma) and the thickness changes induced by compaction clearly indicate the time of emplacement. Hydrothermal mounds are also onlapped by earliest Late Miocene strata, which further confirms the time of magma emplacement within a short period. Because magma-induced deformation always affected the early Late Miocene siliciclastic sediment package, which, on the other hand, onlap the mound structures, we can bracket the magmatic activity between 11.6 to $9.78 \mathrm{Ma}$.

Several fault-parallel intrusions prove that the late Mid-Miocene en-echelon oblique normal faults in the Polgár Trough do not displace intrusions and their fault planes were only passively used during emplacement in the earliest Late Miocene (Fig. 6, s21). This finding of the usage of precursor faults during magma emplacement is similar to other examples described from worldwide (Planke et al., 2005; Magee et al., 2013a). On the other hand, this observation also gives a minimum time constraint for the emplacement of intrusions.

\subsection{MAGMA-FLOW DIRECTION AND POSSIBLE SOURCES}

Strike and long axes of magma flow indicators (e.g. steps, bridges, fingers) have long been used to reconstruct flow patterns (Trude, 2004; Schofield, 2009). Steps and bridges require brittle failure of the host rocks and develop at a greater emplacement depth $(>2 \mathrm{~km})$ while magma fingers are related to host rock distintegration and/or fluidization under ductile deformation regime (Schofield et al., 2010, 2012a). In the study area, the layer-parallel sills revealed the most impressive primary magma flow indicators with the abundance of steps which developed only at 100-500 m emplacement depth (sill 11-23, Figs 6, 9). The reason for the frequency of a brittle and scarcity of a non-brittle deformation pattern at this shallow emplacement depth might be explained by the variable host rock rheology. Alternating claystone, siltstone and sandstone can have laterally and vertically variable degree of cementation. Well-cemented sandstone is more likely to have been deformed in a brittle way as opposed to incompetent, water-saturated claystone or siltstone. Lateral and vertical heterogeneity might be a reason why we can see small-scale undulations (magma fingers) and steps for the same sill on different cross-sections (sill 11, Fig. 9).

The long axes of flow indicators indicate north-westward or south-eastward magma flow direction with small-scale deviation. The nicest steps with NW-SE trending long axes were recognised in the RMS amplitude map of the layer-parallel sills (s11, s23) where the number and the size of steps increase north-westward (Figs 9A, B). The long axes are also diverging and branching in the same direction resulting in multiple and elongated magma-lobes (Figs 9A,B). In addition, the majority of identified sills become shallower in the NW direction (SM6). Mafic intrusions usually propagate from their deepest parts towards the paleosurface (Galland et al., 2009; Schofield et al., 2010). Using the analogy of published flow indicators with similar geometry (Schofield 2009, Reynolds et al. 2017, Schofield et al., 2012b; Sulieman et al., 2017), these features are consistent with intrusion emplacement from SE to NW. Hence, one of the possible magma sources might have been the same as for the Polgár Volcanic Field (PVF).

This article is protected by copyright. All rights reserved. 
There are some slightly saucer-shaped NE-SW elongated intrusions (s13-s15, Fig. 4) where the magma transport mechanism and the direction of magma flow might have been different. According to Galerne et al. (2011), the long, linear feeders produce elliptical geometry of sills. We adopt this explanation, which would suggest NE-SW trending linear feeders which could be potentially fault-controlled.

The majority of sill-sill junctions were 'B' type (Fig 5A/5, Fig. 5A/11) meaning that magma transported through sills which have abutment geometry (' $\mathrm{J}$ ' or ' $\mathrm{F}$ ' type) due to the density of intrusions or bilateral propagation away from transgressive sill tip. Some Mid-Miocene fault planes also contributed to vertically transport magma to the paleosurface (e.g. fault-related sills).

\subsection{VOLCANIC ROCK COMPOSITION AND THEIR TEMPORAL CHANGES IN THE BROADER STUDY AREA}

In passive continental margins, from where comparative seismic data with similar volcanic features are available, the subvolcanic features are related mostly to basaltic magmas (Planke et al., 2005; Holford et al., 2012; Magee et al., 2014). Basalts are common also in continental rift areas. There is, however, only sporadic information about the occurrence of mafic rocks in the Polgár Trough and its vicinity. Near Mezökövesd, 40 km northwest of the study area (Fig. 1B), the Mk-4 drilling penetrated ca. $500 \mathrm{~m}$ thick basaltic andesite with a supposed Late Miocene age based on stratigraphic relations. It has a NW-SE direction along $3 \mathrm{~km}$ length as shown by seismic sections (unpublished data of the authors). At Sárospatak, $60 \mathrm{~km}$ northeast of the area, a borehole revealed small 9 Ma olivine basaltic dykes as part of the TokajSlanské Volcanic Field (Fig. 1A) (e.g. Downes et al., 1995). In contrast, intermediate and felsic rocks are more typical in the close vicinity of the area, in the PVF (rhyolite tuff: HHEHn-1, HHE-Hn-2, Gh-1 boreholes; andesite: Hn-2; Zelenka et al., 2004), in the TVF (trachyte: Tikeszi-1 borehole) and in the SVF (trachyte: Sajóhídvég-2 borehole) (Figs 1B, 4A).

To the east, two volcanic fields could be related to our study area based on the synchronous volcanic activity period and tectonic similarities: Tokaj-Slanské Mts (Hungary-Slovakia) and Oaş-Gutâi Mts (Romania) (Fig. 1A). Both represent complex volcanic fields with dominantly rhyolitic, dacitic and andesitic rocks formed between ca. 14 and $8 \mathrm{Ma}$ (Pécskay et al., 2006).

The final stage of volcanism in both fields is represented by basaltic intrusions (e.g. Downes et al., 1995; Kovacs et al., 2017). This magmatic evolutionary trend, i.e. starting with felsic, followed by intermediate and finished with more mafic (basaltic) magmas could be a general feature during this period in the Carpathian-Pannonian region and reflect the progressive thinning of the lithosphere accompanied with more asthenosphere-derived magmas (Harangi et al., 2007). This trend could be in accordance with more mafic (basaltic) intrusions in the Polgár Trough after the felsic volcanic activity of the surrounding volcanic fields. Since this compositional change is coeval with the volcanism of the Polgár Trough, we cannot unambiguously exclude that significant mafic volcanism occurred also in this area in spite of the lack of drilling information.

This article is protected by copyright. All rights reserved. 
The Polgár Volcanic Field as part of a large volcanic area could represent the latest volcanic events during the earliest Late Miocene (11.6-9.78 Ma). We propose that spatially extended volcanic fields could have been formed at the eastern Pannonian basin during the Late Miocene, which cannot be recognized based on the present surface exposures of the volcanic rocks. According to Seghedi \& Downes (2011), these areas (e.g. Tokaj-Slanské Mts and OaşGutâi Mts) are linked to the widespread magmatism in the Transcarpathian basin which evolved as a result of core-complex extension (Soták et al., 2000) and related counterclockwise rotation (Márton et al., 2007). This could allow flow of lower-middle crust and magma generation. However, we could not find evidence to the core-complex tectonics and the supposed N-S detachment faults in our study area. In our interpretation, the early Late Miocene magmatism may be related to rift-related magma-tectonic processes along ENEWSW trending extensional/transtensional fault zones.

\subsection{TECTONIC CONSEQUENCES}

The earliest Late Miocene volcanic activity was coeval with the D8 deformation phase (Petrik, 2016) (Fig. 11). The NW-SE extension was almost perpendicular to the segmented, basin-bounding Hajdú Fault Zone (Figs. 1, 12A). Our study area is lying in the first-order Mid-Hungarian Fault Zone (MHFZ) which played a crucial role in the Early Miocene extrusion tectonics (Balla, 1984; Csontos et al., 1992; Fodor et al., 1998). We demonstrate here that one segment of this complex fault zone, the NE-SW trending basin-bounding Hajdú Fault was also active during the early Late Miocene (Fig. 12). Similarly directed active faults (e.g.) were documented just north from the study area, in the Vatta-Maklár Trough (Fig. 1, Vatta-Maklár Fault, VMF) (Petrik et al., 2014, Petrik, 2016). Further to the west, RuszkiczayRüdiger et al. (2007) and Palotai \& Csontos (2010) demonstrated sinistral transtensional deformation along the similarly-oriented Tóalmás fault (To), representing the northern branch of the MHFZ (Fig. 1).

Tischler et al. (2007) claimed kinematic linkage and active NW-SE extension along the MFHZ and its eastward continuation along the BVF (Bogdan-Voda Fault) during the same time period ( 12-10 Ma)(Fig. 1). Kovacs et al. (2017) linked the $11.9-9.2$ Ma intermedier intrusions to the same extensional deformation of the BVF. In this scenario, active deformation and magmatism are strongly similar along Pannonian and Transylvanian fault system.

All these examples strengthen the observation (e.g. Balázs et al. 2016) that the early Late Miocene was a tectonically active period, when rifting renewed, or even accelerated, particularly in the eastern basin part where core-complex extension was also claimed (Seghedi \& Downes, 2011). As an expression of this late-stage rifting, earliest Late Miocene volcanism was coeval with the fastest subsidence of the Polgár Trough (11.6-9.78 Ma: $1300 \mathrm{~m})$. This connected deformation and magmatism were probably induced by the late Miocene-Pliocene slab-pull beneath the Eastern Carpathians (Matenco et al., 2007).

This article is protected by copyright. All rights reserved. 


\subsection{MODEL FOR MAGMATISM}

In the study area we described several sills and crater-hosted hydrothermal mounds, which seem to be missing in association with Middle Miocene sediments, although magmatic activity could have been even more important during that time. One important aspect of potential explanation could be in the different sedimentation rates which changed from $\sim 350 \mathrm{~m} /$ Ma during late Mid-Miocene to $\sim 750 \mathrm{~m} /$ Ma during 11.6-9.78 Ma (Petrik, 2016) (Fig. 11). The fast sedimentation rate could influence the deformation geometry and the distribution of magmatic bodies in several ways; an explanatory model is proposed here (Fig. 12).

Magma ascent has been mostly diverted from sub-vertical to horizontal propagation. There are some other examples for diverting magma flow from different areas. For example, a $\sim 40$ $\mathrm{km}$ magma (dyke) emplacement from the central volcanic edifice at the active Bardarbunga volcanic complex (Iceland) was observed during 2014 that is associated with a major spreading event (Gudmundsson et al., 2014) and a similar event occurred in the Kilauea volcanic field at the Big Island, Hawaii in 2018. The direction of magma emplacement was deviated from NE-SW to N-S due to the stress change in Iceland (Gudmundsson et al., 2014), whereas the magma channelled towards east along a rift zone at Hawaii where tensional forces created a weak zone and erupted ca. $40 \mathrm{~km}$ distance from the volcanic center. In case of the Novarupta eruption (Alaska), $10 \mathrm{~km}$ magma flow propagation through dyke system was reported from the magma reservoir to the eruptive vent; this magma propagation was oriented by the pre-existence fissures and joints and the regional stress directions (Wallmann et al., 1990). Maccaferri et al. (2014) identified the main factors in the evolution of off-rift volcanic structures and they concluded that gravitational unloading pressure, tectonic stretching and the aspect ratio of the rift depression determine in-rift or off-rift dyke propagation.

In our case, the style of reactivation of Hajdú Fault Zone (HF) could have played a role in controlling magma flow direction. The HF was a NE-SW trending continuous fault with sinistral strike-slip kinematics during the main late Mid-Miocene volcanic activity (D6-D7 phase) (Figs. 11, 12B). The magma flow might have occurred only south of the continuous Hajdú Fault Zone which prevented flow toward the basin centre (Fig. 12B). However, the Hajdú Fault Zone became segmented during the D8 phase. Segmentation could be explained by slight stress field change (from D7 to D8) resulted in several non- or slightly overlapping NE-SW trending segments (Figs 12A, C). The oblique extensional reactivation of preexisting fault generated en echelon faults in the sedimentary cover in the fault-linkage models proposed by e.g. Soliva \& Schulz (2008) and Fossen \& Rotevatn (2016). The segmented fault geometry could permit magma flow toward the basin axis, where the ascending magma passively used the pre-existing faults as final steps on its pathways (Figs 12A,C).

Once magma flow was diverted toward the graben, fast accumulation of water-saturated sediments might have prevented the magma from rising on the surface. If the water/magma ratio significantly exceeds the $\sim 0.3$ ratio (Wohletz, 1983; Sheridan \& Wohletz, 1983), phreatomagmatic/magmatic explosions may be suppressed and the magma emplaces in shallow subsurface level parallel to a discontinuity surface (e.g. bedding planes). In addition, this water content, and fast sedimentation rate could partly prevent formation of forced folds

This article is protected by copyright. All rights reserved. 
above some sills. Finally, the water content contributed to the development of magma-poor hydrothermal mounds to develop, mostly above tips of sills and splay faults. Interaction of high sedimentation rate and magmatism is not typical in earlier phase of evolution; this can explain why the described features is not typical (rarely seen) in Middle Miocene formations. In summary, fault reactivation, a change from connected to segmented fault geometry, and the increase in sedimentation rate as well as water content, all could contribute to the change in style of volcanism in the eastern part of the Pannonian Basin.

\section{CONCLUSIONS}

In this study, we revealed a new magma-tectonic system in a first-order tectonic zone of the extensional Pannonian Basin, which was active in the earliest Late Miocene. The combined interpretation of 3D seismic, borehole and log data, along with neural network analysis detected a great variety of intrusions (sills), fluid-escape structures and volcanic mounds which were, in general, poorly documented in onshore areas before.

In our interpretation, the style of magmatic activity has changed from the Middle Miocene build-up of volcanic mounds along basin-margin faults to the earliest Late Miocene emplacement of intrusions and development of hydrothermal mounds. The 11.6-9.78 Ma timing was confirmed by intrusion-related deformation patterns including onlapped forced folds and hydrothermal mounds. The reasons for this change can be explained by: 1) the segmented en-echelon geometry of basin-bounding Hajdú Fault Zone; this geometry could have facilitated the magma emplacement between fault segments from the Polgár Volcanic Field toward the Polgár Trough; 2) the change in stress field was associated with faster accumulation rate which, together with the deposition of water-saturated sediments, prevented magma from rising on the surface; 3) the water content contributed to the development of magma-poor hydrothermal mounds to develop; this is a feature not typical (rarely seen) in older formations. In addition, this water content, and fast sedimentation rate could partly prevent formation of forced folds above some sills.

The revealed volcanic features can be related to similar volcano-tectonic processes described along strike near the Bogdan-Voda Fault and might be present in other segments of the MidHungarian Fault Zone.

This article is protected by copyright. All rights reserved. 


\section{ACKNOWLEDGEMENTS}

The research was supported by the Hungarian National Research, Development and Innovation Fund (NKFIH) within three research projects (OTKA No. 81530, 113013 and FK128312). We are grateful to the Hungarian Horizon Ltd. and MOL Ltd. and the Mining and Geological Survey of Hungary for providing us with seismic and borehole data. We are grateful to Imre Magyar, Orsolya Sztanó, Katalin Lörincz and János Kiss for discussions, reviews and help in interpretation. We would like to give special thanks to Craig Magee and Christopher Jackson for providing useful comments on the earlier version of the manuscript paper. Editorial help of Cynthia Ebinger and thorough review of Márton Palotai, Nick Schofield and Ioan Seghedi are highly acknowledged. We are grateful to Benjamin van Wyk de Vries for English language improvement of the manuscript.

This article is protected by copyright. All rights reserved. 


\section{REFERENCES}

BaCon, M., Simm, R. \& Redshaw, T. (2007) 3-D seismic interpretation. Cambridge University Press, Cambridge.

Bada, G., Horváth, F., Dövényi, P., Szafián, P., Windhoffer, G. \& Cloetingh, S. (2007) Present-day stress field and tectonic inversion in the Pannonian Basin. Glob. Plan. Change, 58, 165-180.

BALLA, Z. (1984) The Carpathian loop and the Pannonian basin: a kinematic analysis. Geophys. Trans., 30 (4), 313-353.

Balázs, A., Matenco, L., Magyar, I., Horváth, F. \& Cloetingh, S. (2016) The link between tectonics and sedimentation in back-arc basins: New genetic constraints from the analysis of the Pannonian Basin. Tectonics, doi: 10.1002/2015TC004109.

BARANYI, V. (2013) A palynological study of the Tiszavasvári-6 well. Unpublished report, Eötvös University, Budapest, Hungary, 1-12.

BARANYI, V. (2016) A palynological study of the Tiszavasvári-6 well, interval 2585m2783m. Unpublished report, University of Oslo, Norway, 1-7.

BAaske, U.P, MutTi, M., BAiOni, F., BertozZI, G. \& NAini, M.A. (2007) Using multiattribute neural networks classification for seismic carbonate facies mapping: A workflow example from mid-cretaceous Persian Gulf deposits. Geol. Soc. London Spec. Publ., 277, $105-120$.

BRown, A.R. (2004) Interpretation of three-dimensional seismic data, 6th Edition. AAPG Memoir 42/SEG Investigations in Geophysics No.9.

Chevalier, L. \& Woodford, A. (1999) Morph-tectonics and mechanism of emplacement of the dolerite rings and sills of the western Karoo, South Africa. S. African J. Geol., 102, $43-$ 54.

Ciulavu, D., Dinu, C., Szakács, A. \& Dordea, D. (2000) Neogene kinematics of the Transylvanian basin (Romania). AAPG Bulletin, 84, 1589-1615.

Ciulavu, D., Dinu, C. \& Cloetingh, S. (2002) Late Cenozoic tectonic evolution of the Transylvanian basin and northeastern part of the Pannonian basin (Romania): Constraints from seismic profiling and numerical modelling. EGU Stephan Mueller Spec. Publ. Series, 3, $105-120$.

Cosgrove, J.W. \& HiLliER, R.D. (1999) Forced-fold development within Tertiary sediments of the Alba Field, UKCS: evidence of differential compaction and post-depositional sandstone remobilization. In: Forced Folds and Fractures (Eds. by J.W. Cosgrove \& M.S. Ameen), Geol. Soc. London Spec. Publ., 169, 61-71.

Csontos, L., Nagymarosy, A., Horváth, F. \& KovÁC M. (1992) Cenozoic evolution of the Intra-Carpathian area: a model. Tectonophysics, 208, 221-241.

This article is protected by copyright. All rights reserved. 
Dombrádi, E., Sokoutis, D., BAdA, G., Cloetingh, S. \& Horváth, F. (2010) Modelling recent deformation of the Pannonian lithosphere: Lithospheric folding and tectonic topography. Tectonophysics, 484 (1-4), 103-118.

Downes, H., PAntó, G., PóKa, T., MATtey, D. \& Greenwood, B. (1995) Calc-alkaline volcanics of the Inner Carpathian arc, Northern Hungary: New geochemical and oxygen isotopic results. In: Neogene and Related Magmatism in the Carpatho-Pannonian Region (Eds.by H. Downes \& O. Vaselli), Acta Vulcanologica, 7, 29-41.

Eide, C.H., Schofield, N., Jerram, A.D. \& Howell, J.A. (2017a) Basin-scale architecture of deeply emplaced sill complexes: Jameson Land, East Greenland. J. Geol. Soc., 174, 23-40.

Eide, C.H., Schofield, N., LeCOMte, I., Buckley, S.J. \& Howell, J.A. (2017b) Seismic interpretation of sill-complexes in sedimentary basins: The 'sub-sill imaging problem'. $J$. Geol. Soc., doi: 10.1144/jgs2017-096.

Fodor, L., Jelen, B., MÁrton, E., Skaberne, D., ČAR, J. \& Vrabec, M. (1998) MiocenePliocene tectonic evolution of the Slovenian Periadriatic Line and surrounding area implication for Alpine-Carpathian extrusion models. Tectonics, 17, 690-709.

Fodor, L., CsOntos, L., BADA, G., GyÖRFY, I. \& BenKoviCs, L. (1999) Tertiary tectonic evolution of the Pannonian basin system and neighbouring orogens: a new synthesis of paleostress data. In: The Mediterranean Basins: Tertiary extension within the Alpine Orogen (Eds. by B. Durand, L. Jolivet, Horváth, F. \& M. Séranne), Geol. Soc. London Spec. Publ., 156, 295-334.

Fossen, H. \& Rotevatn, A. (2016) Fault linkage and relay structures in extensional settings A review. Earth-Science Reviews, 154, 14-28.

FÖLDESSY, J. \& KUPI, L. (2009) Geological drill core log of the interval 1225-1243.73m of the SEE/PHGH1 Drill Hole. In: Petrophysical properties of reservoir rocks Well GH-1(Eds. by T. Bódi \& J. Tóth), University of Miskolc, Research Institute of Applied Earth Sciences, $27-37$.

Galerne, C.Y., Galland, O., Neumann, E-R., Planke, S. (2011) 3D relationships between sills and their feeders: evidence from the Golden Valley Sill Complex (Karoo Basin) and experimental modelling. J. Volc. Geoth. Res., 202, 189-199.

Galland, O., Planke, S., Neumann, E.-R. \& Malthe-Sørenssen, A. (2009) Experimental modelling of shallow magma emplacement: application to saucer-shaped intrusions. Earth Plan. Sci. Let., 277 (3), 373-383.

GiFKINS, C.C. \& AlLEN, R.L. (2001) Textural and chemical characteristics of diagenetic and hydrothermal alteration in glassy volcanic rocks: examples from the Mount Read Volcanics, Tasmania. Economic Geology, 96 (5), 973-1002.

GÖRÖG, Á., TóTH, E. \& SzENTESI, Z. (2010) Micropaleontological study on cuttings of Tiszavasvári-6 well. Part II. Unpublished report, Eötvös University, Budapest, 1-5.

Gudmundsson, A., Lecoeur, N., Mohajeri, N. \& Thordarson, T. (2014) Dike emplacement at Bardarbunga, Iceland, induces unusual stress changes, caldera formation, and earthquakes. Bull. Volcanol., 76, 869.

This article is protected by copyright. All rights reserved. 
HANSEN, D.M. \& CARTwright, J. (2006a) The three-dimensional geometry and growth of forced folds above saucer-shaped igneous sills. J. Struct.Geol., 28, 1520-1535.

HANSEN, D.M. \& CARTWRIGHT, J. (2006b) Saucer-shaped sills with lobate morphology revealed by 3D seismic data: implications for resolving a shallow-level sill emplacement mechanism. J. Geol. Soc., 163, 509-523.

Hansen, D.M., Cartwright, J.A. \& Thomson, D. (2004) 3D seismic analysis of the geometry of igneous sills and sill interaction relationships. In: 3D seismic technology: Application to the exploration of sedimentary basins (Eds. by R.J. Davies, J. Cartwright, S.A. Stewart, J.R. Underhill \& M. Lappin), Geol. Soc. London Spec.Publ., 29, 199-208.

Hansen, J.P.V., CARTwright, J.A., Huuse, M. \& Clausen, O.R. (2005) 3D seismic expression of fluid migration and mud remobilization on the Gjallar Ridge, Offshore MidNorway. Basin Res., 17, 123-139.

HARANGI, S. (2001) Neogene to Quaternary volcanism of the Carpathian-Pannonian regionA review: Acta Geol. Hung., 44, 223-258.

HARANGI, S. \& LENKEY, L. (2007) Genesis of the Neogene to Quaternary volcanism in the Carpathian-Pannonian Region: role of subduction, extension and mantle plume. In: Cenozoic volcanism in the Mediterranean area (Eds. by L. Beccaluva, G. Bianchini \& M. Wilson), Geol. Soc. Am. Spec. Publ., 418, 67-92.

Harangi, S., Downes, H., Kósa, L., Szabó, C., Thirlwall, M.F., Mason, P.R.D. \& MATTEY, D. (2001) Almandine garnet in calc-alkaline volcanic rocks of the northern Pannonian Basin (Eastern-Central Europe): Geochemistry, petrogenesis and geodynamic implications. J. Petrology, 42, 1813-1843.

Harangi, S., Downes, H., Thirlwall, M.F. \& GMÉling, K. (2007) Geochemistry, Petrogenesis and Geodynamic Relationships of Miocene Calc-alkaline Volcanic Rocks in the Western Carpathian Arc, Eastern Central Europe. J. Petrology, 48 (12), 2261-2287.

HART, B.S. (2008) Channel detection in 3-D seismic data using sweetness. AAPG Bulletin, 92, 733-742.

Hohenegger, J., Coric, S., Khatun, M., Pervesler, P., Rögl, F., Rupp, C., Selge, A., UChMANn, A. \& WAGREICH, M. (2009) Cyclostratigraphic dating in the Lower Badenian (MiddleMiocene) of the Vienna Basin (Austria): the Baden-Sooss core. Int. J. Earth Sci., 98, 915-930.

Holford, S.P., Schofield, N., Macdonald, J.D., Duddy, I.R. \& GreEn, P.F. (2012) Seismic analysis of igneous systems in sedimentary basins and their impacts on hydrocarbon prospectivity: examples from the Southern Australian margin. Austr.Petr.Prod. Exp.Assoc. J., 52, 229-252.

Holford, S.P., Schofield, N., Jackson, C.A-L., Magee, C., Green, P.F. \& DudDy, I.R. (2013) Impacts of igneous intrusions on source and reservoir potential in prospective sedimentary basins along the Western Australian Continental Margin. West Australian Basins Symposium, Perth WA, 1-11.

This article is protected by copyright. All rights reserved. 
HoRVÁth, F. (1993) Towards a mechanical model for the Pannonian Basin. Tectonophysics, 226, 333-358.

Horváth, F., Musitz, B., Balázs, A., Végh, A., Uhrin, A., Nádor, A., Koroknai, B., PaP, N., Tóth, T. \& WóRuM, G. (2015) Evolution of the Pannonian basin and its geothermal resources. Geothermics, 53, 328-352.

JACKSON, C.A-L. (2012) Seismic reflection imaging and controls on the preservation of ancient sill-fed magmatic vents. J. Geol. Soc., 169, 503-506.

JACKSON, C.A-L., SCHOFIELD, N. \& GolenKOV, B. (2013) Geometry and controls on the development of igneous sill-related forced folds: a 2D seismic reflection case study from offshore southern Australia. Geol. Soc. Am. Bull., 125 (11-12), 1874-1890.

Jamtveit, B., Svensen, H., Podladchikov, Y. \& Planke, S. (2004) Hydrothermal vent complexes associated with sill intrusions in sedimentary basins. In: Physical Geology of High-Level Magmatic Systems (Eds. by C. Breitkreuz \& N. Petford), Geol. Soc. London Spec. Publ., 234, 233-241.

KÁZMÉR, M. \& KovÁCS, S. (1985) Permian-Palaeogene palaeogeography along the eastern part of the Insubric-Periadriatic lineament system: evidence for continental escape of the Bakony-Drauzug unit. Acta Geol. Hung., 28, 71-84.

KISS, J. (2013) Hungarian geomagnetic data set and data processing: spectral analysis and grid data processing. M. Geof., 54 (2), 89-114 (in Hungarian with English abstract).

KISS, J. (2016) Comprehensive interpretation of gravity and magnetic anomalies in Carpathian-Pannonian Region. Földt. Közl., 146(3), 275-298 (in Hungarian with English abstract)

KISS, J. \& GULYÁs, Á. (2006) Magnetic $\Delta \mathrm{z}$ anomaly map of Hungary, 1:500 000. Eötvös Loránd Geophysical Institute of Hungary.

KITSOPOULOS, K. (1997) The genesis of a mordenite deposit by hydrothermal alteration of pyroclastics on Polyegos Island, Greece. Clays and Clay Minerals, 45 (5), 632-648.

Klarner, S. \& KlaRner, O. (2012) Identification of Paleo-Volcanic Rocks on Seismic Data. In: Updates in Volcanology - A Comprehensive Approach to Volcanological Problems (Ed. by F. Stoppa), pp. 181-206. InTech, Rijeka, Croatia.

Koch, F.G., Johnson, A.M. \& Pollard, D.D. (1981) Monoclinal bending of strata over laccolithic intrusions. Tectonophysics, 74, T21-T31.

KoneČnÝ, V., KovÁc, M., LEXA, J. \& ŠEFARA, J. (2002) Neogene evolution of the CarpathoPannonian region: An interplay of subduction and back-arc diapiric uprise in the mantle. EGU, Stephan Mueller Spec. Publ. Series, 1, 105-123.

Kovács, I., Falus, Gy., Stuart, G., Hidas, K., Szabó, Cs., Flower, M.F.J., Hegedüs, E., POSGAY, K. \& ZILAHI-SEBESS, L. (2012) Seismic anisotropy and deformation patterns in upper xenoliths from the central Carpathian-Pannonian region: Asthenospheric flow as a driving force for Cenozoic extension and extrusion? Tectonophysics, 514-517 (5), 168-179.

This article is protected by copyright. All rights reserved. 
Kovacs, M., Seghedi, I., Yamamoto, M., FülÖP, A., PÉcskay, Z. \& JuRJe, M. (2017)

Miocene volcanism in the Oaş-Gutâi Volcanic Zone, Eastern Carpathians, Romania:

Relationship to geodynamic processes in the Transcarpathian Basin. Lithos, 294-295, 304-

318.

LeE, G.H., Young, I.K., Yoon, C.S., KiM, H.J. \& Yoo, H.S. (2006) Igneous complexes in the eastern Northern South Yellow Sea Basin and their implications for hydrocarbon systems.

Mar. Petr. Geol., 23, 631-645.

LEXA, J. \& KONEČnÝ, V. (1974) The Carpathian volcanic arc: A discussion. Acta Geol.

Hung., 18, 279-294.

Lourens, L., Hilgen, F., Shackleton, N.J., Laskar, J. \& Wilson, D. (2004) The Neogene

Period. In: A Geologic Time Scale 2004 (Eds. by F.M. Gradstein, J.G. Ogg, A.G. Smith), pp. 409-440. Cambridge Univ. Press, Cambridge.

Lukács, R., Harangi, S., Bachmann, O., Guillong, M., Danisik, M., Von Quadt, A., DUNKL, I., FODOR, L., SLIWINSKI, J., SOÓS, I. \& SZEPESI, J. (2015) Zircon geochronology and geochemistry to constrain the youngest eruption events and magma evolution of the MidMiocene ignimbrite flare-up in the Pannonian Basin, eastern-central Europe. Contr. Miner. Petr., 170 (5-6), 1-26.

Lukács, R., Harangi, S., Guillong, M., Bachmann, O., Fodor, L., Buret, Y., Dunkl, I., Sliwinski, J., von QuAdT, A., PeYTCheva, I. \& Zimmerer, M. (2018) Early to Mid-Miocene syn-extensional massive silicic volcanism in the Pannonian Basin (East-Central Europe): eruption chronology and geodynamic relations. Earth Sci. Rev., 179, 1-19.

Maccaferri, F., Rivalta, E., KeIR, D. \& Acocella, V. (2014) Off-rift volcanism in riftzones determined by crustal loading. Natural Geoscience, 7, 297-300.

MAgeE, C., JACKSON, C.A-L. \& SchOFIELD, N. (2013a) The influence of normal fault geometry on igneous sill emplacement and morphology. Geology, doi: 10.1130/G33824.1.

Magee, C., Hunt-Stewart, E. \& Jackson, C.A-L. (2013b) Volcano growth mechanisms and the role of sub-volcanic intrusions: Insights from 2D seismic reflection data. Earth Plan. Sci. Let., 373, 41-53.

MAGEE, C., JACKSON, C.A-L. \& SCHOFIELD, N. (2014) Diachronous sub-volcanic intrusion along deep-water margins: insights from the Irish Rockall Basin. Basin Res., 26, 85-105.

Magee, C., MaharaJ, S.M., Wrona, T. \& Jackson, C. A-L. (2015) Controls on the expression of igneous intrusions in seismic reflection data. Geosphere, 11 (4), 1024-1041.

Magee, C., Duffy, O.B., Purnell, K., Bell, R.E., Jackson, C.A.L. \& Reeve, M.T. (2016) Fault-controlled fluid flow inferred from hydrothermal vents imaged in 3D seismic reflection data, offshore Australia. Basin Res., 28, 299-318.

Magyar, I., Geary, D.H. \& MüLler, P. (1999) Paleogeographic evolution of the Late Miocene Lake Pannon in Central Europe. Palaeogeogr.Palaeoclimatol. Palaeoecol., 147, $151-167$.

This article is protected by copyright. All rights reserved. 
Magyar, I., Radivojević, D., Sztanó, O., Synak, R., Ujszászi, K. \& Pócsik, M. (2013) Progradation of the paleo-Danube shelf margin across the Pannonian Basin during the Late Miocene and Early Pliocene. Glob. Plan. Change, 103, 168-173.

Malthe-Sørenssen, A., Planke, S., Svensen, H. \& Jamtveit, B. (2004) Formation of saucer-shaped sills. In: Physical Geology of Highlevel Magmatic Systems (Eds. by C. Breitkreuz \& N. Petford), Geol. Soc. London Spec. Publ., 234, 215-227.

Malvić, T., Velić, J., HoRváth, J. \& CVetKović, M. (2010) Neural networks in petroleum geology as interpretation tools. Cent. Eur. Geol., 53 (1), 97-115.

Marantos, I., Christidis, G.E. \& Ulmanu, M. (2011) Zeolite formation and deposits. In: Handbook of natural zeolites (Eds. by Inglezakis, V.J. \& Zorpas, A.A.) pp. 19-36. Bentham Science Publishers.

Mark, J.N., Schofield, N., Pugliese, S., Watson, D., Holford, S., Muirhead, D., BROWN, R. \& HEALY, D. (2018) Igneous intrusions in the Faroe Shetland basin and their implications for hydrocarbon exploration; new insights from well and seismic data. Mar. Petr. Geol., 92, 733-753.

Matenco, L., Bertotti, G., Leever, K., Cloetingh, S., Schmid, S.M., TĂrăPOAnCĂ, M. \& DINU, C. 2007. Large-scale deformation in a locked collisional boundary: Interplay between subsidence and uplift, intraplate stress and inherited lithospheric structure in the late stage of the SE Carpathians evolution. Tectonics, 26, https://doi.org/10.1029/2006TC001951.

Márton, E., Tischler, M., Csontos, L., Fügenschuch, B. \& Schmid, S. (2007) The contact zone between the ALCAPA and Tisza-Dacia mega-tectonic units of Northern Romania in the light of new paleomagnetic data. Swiss J. Geosci.,100 (1), 109-124.

Neubauer, F. \& Genser, J. (1990) Architectur und kinematik der östlichen Zentralalpen eine übersicht. Mitteilungen des Naturwissenschaftlichen Vereines für Steiermark, 120, 203 219.

Palotai, M. \& Csontos, L. (2010) Strike-slip reactivation of a Palaeogene to Miocene fold and thrust belt along the central part of the Mid-Hungarian Shear Zone. Geol. Carp., 61 (6), 483-493.

PÉCSKAY, Z. \& MOLNÁR, F. (2002). Relationships between volcanism and hydrothermal activity in the Tokaj Mountains, northeast Hungary, based on K-Ar ages. Geol. Carp., 53 (5), 303-314.

Pécskay, Z., LeXa, J., SZakács, A., Seghedi, I., Balogh, K., KoneČnÝ, V., Zelenka, T., Kovacs, M., Póka, T., FÜlöP, A., Márton, E., PAnaiotu, C. \& CvetKović, V. (2006) Geochronology of Neogene magmatism in the Carpathian arc and intra-Carpathian area. Geol. Carp., 57, 511-530.

Petrik, A., BeKE, B. \& FodOR, L. (2014) Combined analysis of faults and deformation bands reveals the Cenozoic structural evolution of the southern Bükk foreland (Hungary).

Tectonophysics, 633, 43-62.

This article is protected by copyright. All rights reserved. 
Petrik, A. (2016) Cenozoic structural evolution of the southern Bükk foreland. Ph.D Dissertation, Eötvös University, Dept. of Applied and Physical Geology, Budapest.

Planke, S., Rasmussen, T., Rey, S.S. \& Myklebust, R. (2005) Seismic characteristics and distribution of volcanic intrusions an hydrothermal vent complexes in the Voring and More basins. In: Petroleum Geology: Northwest Europe and Global Perspectives-proceedings of the Sixth Petroleum Conference (Eds. by A.G. Doré \& B. Vining), Geol. Soc. London, Petr. Geol. Conf. S., 6, 833-844.

Planke, S., Svensen, H., Myklebust, R., Bannister, S., Manton, B. \& Lorenz, L. (2014)

Geophysics and Remote Sensing. In: Physical Geology of Shallow Magmatic Systems (Ed. by S. Rocchi) pp.1-16. Springer International Publishing, Switzerland.

PogÁcsÁs, Gy., MAtTick, R.E., Elston, D.P., HÁmor, T., JÁMBor, Á., LAKATOS, L., LAntos, M., Simon, E., VAKarcs, G., VÁrkonyi, L. \& VÁRnai, P. (1994) Correlation of Seismo- and Magnetostratigraphy in southeastern Hungary. In: Basin Analysis in Petroleum Exploration: A case study from the Békés basin, Hungary (Eds. by P.G. Teleki, R.E. Mattick \& J. Kókai), pp. 143-160. Kluwer Academic Publishers.

Pollard, D.D. \& Johnson, A.M. (1973) Mechanics of growth of some laccolithic intrusions in the Henry Mountains, Utah, II: bending and failure of overburden layers and sill formation. Tectonophysics, 18, 311-354.

Polteau, S., Ferre, E.C., Planke, S., Neumann, E.R. \& Chevallier, L. (2008) How are saucer-shaped sills emplaced? Constraints from the Golden Valley Sill, South Africa. $J$. Geophys. Res., 113, B12104.

RADOVICH, B.J. \& OLIVEROS, R.B. (1998) 3D sequence interpretation of seismic instantaneous attributes from the Gorgon Field. The Leading Edge, 17, 1286-1293.

RAEesi, M., MoradZADEH, A., ARdeJANI, F.D. \& RAHIMI, M. (2012) Classification and identification of hydrocarbon reservoir lithofacies and their heterogeneity using seismic attributes, logs data and artificial neural networks. J. Petr. Sci. Engineer., 82-83, 151-165.

Ratschbacher, L., Frisch, W., Neubauer, F., Schmid, S. \& Neugebauer, J. (1989) Extension in compressional orogenic belts: The Eastern Alps. Geology, 17, 404-407.

Reynolds, P., Holford, S., Schofield, N. \& Ross, A. (2017) The shallow depth emplacement of mafic intrusions on a magma-poor rifted margin: An example from the Bight Basin, Southern Australia, Mar. Petr. Geol., doi: 10.1016/j.marpetgeo.2017.09.008.

Roberts, K.S., DAVIES, R.J., StewART, S.A. \& Tingay, M. (2011) Structural controls on mud volcano vent distributions: examples from Azerbaijan and Lusi, East Java. J. Geol. Soc., 168, 1013-1030.

Royden, L.H. \& HoRvÁth, F. (1988) The Pannonian basin - A study in basin evolution. AAPG Memoir, 45, 1-394.

RUSZKICZAY-RÜDIGER, Zs., FODOR, L. I. \& HoRVÁTH, E. (2007) Neotectonics and Quaternary landscape evolution of the Gödöllö Hills, Central Pannonian Basin, Hungary.

Glob.Plan.Change, 58 (1-4), 181-196.

This article is protected by copyright. All rights reserved. 
SAGGAF, M., TOKSÖZ, M.N. \& MustAFA, H.M. (2003) Estimation of reservoir properties from seismic data by smooth neural networks. Geophysics, 68 (6), doi.org/10.1190/1.1635051

SĂNDUlescu, M. (1988) Cenozoic tectonic history of the Carpathians. In: The Pannonian basin - A study in basin evolution (Eds. by L. Royden \& F. Horváth), AAPG Memoir, 45, 1725 .

Schmid, S.M., Bernoulli, D., FÜGenschuch, B., MAtenco, L., SchefFer, S., Schuster, R., Tischler, M. \& UstaszewsKI, K. (2008) The Alpine-Carpathian-Dinaridic orogenic system: correlation and evolution of tectonic units. Swiss J. Geosci.,101, 139-183.

SCHOFIELD, N. (2009) Linking sill morphology to emplacement mechanisms. Ph.D Dissertation, University of Birmingham, Dept. of Earth Sciences, Birmingham.

Schofield, N., SteVenson, C. \& Reston, T. (2010) Magma fingers and host rock fluidization in the emplacement of sills. Geology, 38, 63-66.

Schofield, N.J., BRown, D.J., MAgee, C. \& SteVenson, C.T. (2012a) Sill morphology and comparison of brittle and nonbrittle emplacement mechanisms. J. Geol. Soc., 169, 127-141.

Schofield, N., Heaton, L., Holford, S. P., Archer, S. G., Jackson, C. A.-L. \& Jolley, D. W. (2012b) Seismic imaging of 'broken bridges': linking seismic to outcrop-scale investigations of intrusive magma lobes. J. Geol.Soc.,169 (4), 421-426.

Schofield, N., Holford, S., Millett, J., Brown, D., Jolley, D., Passey, SR., Muirhead, D., Grove, C., Magee, C., Murray, J., Hole, M., Jackson, CAL. \& Stevenson, C. (2017a) Regional Magma Plumbing and emplacement mechanisms of the Faroe-Shetland Sill Complex: Implications for magma transport and petroleum systems within sedimentary basins. Basin Res., 29 (1), 41-63.

Schofield, N., Jolley, D., Holford, S., Archer, S., Watson, D., Hartley, A., Howell, J., Muirhead, D., Underhill, J. \& Green, P. (2017b) Challenges of future exploration within the UK Rockall Basin. J. Geol. Soc. Petr. Geol. Conf. Ser.,8, 211-229.

SEGHEDI, I. \& DownES, H. (2011) Geochemistry and tectonic development of Cenozoic magmatism in the Carpathian-Pannonian region. Gondwana Research, 20, 655-672.

Seghedi, I., Downes, H., Szakács, A., Mason, P.R.D., Thirlwall, M.F., Rosu, E., PÉCSKAy, Z., MÁRton, E. \& PANAiOTU, C. (2004) Neogene to Quaternary magmatism and geodynamics in the Carpathian-Pannonian region: a synthesis. Lithos, 72, 117-146.

SHERIDAN, M.F. \& WOHLETZ, K.H. (1983) Hydrovolcanism: basic considerations and review. J. Volc. Geoth. Res., 17, 1-29.

Soliva, R. \&SchUlTZ, R.A. (2008) Distributed and localized faulting in extensional settings: insight from the North Ethiopian Rift-Afar transition area. Tectonics, 27(2), 1-19.

SotÁk, J., Biroñ, A., ProkeŠová, R. \& Spišiak, J. (2000) Detachment control of core complex exhumation and back-arc extension in the East Slovakian Basin. Slovak Geol. Mag., $6(2-3), 130-132$.

This article is protected by copyright. All rights reserved. 
Suleiman, A., Magee, C., Jackson, C.-L. \& Fraser, A. (2017) Igneous activity in the Bornu Basin, onshore NE Nigeria; implications for opening of the South Atlantic. J. Geol. Soc.,174, 667-678.

Svensen, H., Jamtveit, B., Planke, S. \& Chevallier, L. (2006) Structure and evolution of hydrothermal vent complexes in the Karoo Basin, South Africa. J. Geol. Soc., 163, 671-682.

Szabó, C., HARAnGI, S. \& Csontos, L. (1992) Review of Neogene and Quaternary volcanism of the Carpathian-Pannonian region. Tectonophysics, 208, 243-256.

SZÉKY-FuX, V., PÉCSKAY, Z. \& BALOGH, K. (1987) Buried Miocene volcanites of Northern and central Tiszántúl, E. Hungary, and their K/Ar radiometric chronology. Földt. Közl., 177, $223-235$.

SZÉKY-FuX, V., KOZÁK, M. \& PÜSPÖKI, Z. (2007) Covered Neogene magmatism in eastern Hungary. Acta GGM Debrecina Geol.Geomorph. Phys.Geogr., 2, 79-104.

Sztanó, O., Szafián, P., Magyar, I., Horányi, A., Bada, G., Hughes, D.W., Hoyer, D.L. $\&$ WALLIS, R.J. (2013) Aggradation and progradation controlled clinothems and deep-water sand delivery model in the Neogene Lake Pannon, Makó Trough, Pannonian Basin, SE Hungary. Glob. Plan. Change, 103, 149-167.

TARI, G., HoRvÁth, F. \& RUMPLER, J. (1992) Styles of extension in the Pannonian basin, Tectonophysics, 208, 203-219.

ter Borgh, M., Vasiliev, I., Stoica, M., Knežević, S., Matenco, L., Krijgsman, W., Rundić, L. \& Cloetingh, S. (2013) The isolation of the Pannonian basin (Central Paratethys): New constraints from magnetostratigraphy and biostratigraphy. Glob. Plan. Change, 103, 99-118.

ThOMSON, K. \& HutTon, D. (2004) Geometry and growth of sill complexes: insights using 3D seismic from the North Rockall Trough. Bull. Volcanol., 66 (4), 364-375.

TISCHLER, M., GRÖGER, M., FÜGEnSCHUCH, B. \& SCHMID, S.M. (2007) Miocene tectonics of the Maramures area (Northern Romania): implications for the Mid-Hungarian fault zone. Int. J. Earth Sci., 96, 473-496.

TIVEY, M. (2016) Black and White Smokers. In: Encyclopedia of Marine Geosciences (Eds. by J. Hariff, M. Meschede, S. Petersen \& J. Thiede), pp. 58-62. Springer Verlag, Berlin.

TRUDE, K.J. (2004) Kinematic indicators for shallow level igneous intrusion from 3D seismic data; evidence of flow direction and feeder location. In: 3D Seismic Technology: Application to the Exploration of Sedimentary Basins (Eds. by R.J. Davies, J.A. Cartwright, S.A. Stewart, M. Lappin \& J.R. Underhill), Geol. Soc. London, Memoirs, 29, 209-217.

WaLKER, R. (2016) Controls on transgressive sill growth. Geology, 44, 99-102.

Wallmann, P.C., Pollard, D.D., Hildreth, W. \& Eichelberger, J.C. (1990) New structural limits on magma chamber locations at the Valley of Ten Thousand Smokes, Katmai National Park, Alaska. Geology, 18, 1240-1243.

This article is protected by copyright. All rights reserved. 
WeSt, B.P., MAY, S.R., EAstwood, J.E. \& Rossen, C. (2002) Interactive seismic facies classification using textural and neural networks. The Leading Edge, 21 (10), 1042-1049.

WoHLETZ, K.H. (1983) Mechanism of hydrovolcanic pyroclast formation: grain-size, scanning electron microscopy and experimental studies. J. Volc. Geoth. Res., 17, 31-63.

ZELENKA, T., BALÁZS, E. \& BALOGH, K. (2004) Buried Neogene volcanic structures in Hungary. Acta Geol. Hung., 47 (2), 177-219.

ZHAO, T., JAYARAM, V., RoY, A. \& MARFURT, K.J. (2015) A comparison of classification techniques for seismic facies recognition. Interpretation, 3-4, SAE29-SAE58.

Zhao, F., Alves, T.M, Wu, S., LI, W., HuUse, M., Mi, L., Sun, Q. \& MA, B. (2016)

Prolonged post-rift magmatism on highly extended crust of divergent continental margins (Baiyun Sag, South China Sea). Earth Plan. Sci. Let., 445, 79-91.

This article is protected by copyright. All rights reserved. 


\section{FIGURE CAPTIONS}

Figure 1. (A) The early Late Miocene regional tectonic map of the Carpathian-Pannonian Basin modified and complemented after Fodor et al. (1999). Faults in the Romanian part of the basin were derived from Ciulavu et al. (2000, 2002) and Tischler et al. (2007). Major faults in the Tisza-Dacia unit were derived from Horváth et al. (2015) and Balázs et al. (2016). (B) Pre-Neogene basement map of the broader study area including major fault lines, traces of the presented seismic profiles (Arb1Arb3) and important boreholes. PTB: Pre-tercier basement.

Figure 2. Generalized stratigraphic column and the key tectonic elements of the study area. Note the pre-, syn and post-rift suites of the Pannonian Basin. The pre-rift/syn-rift boundary is only presumed. Standard stages and their absolute ages are based on Lourens et al. (2004). Central Paratethys stages and their absolute ages are based on Hohenegger et al. (2009).

Figure 3.Interpreted seismic reflection profile of the Arbitrary line 1. The trace of this profile can be seen on the Fig. 1B. Note the key stratigraphic horizons and their absolute ages are derived from the magnetostratigraphic calibration of Tp-1 borhole (Pogácsás et al., 1994). Note the key tectonic elements including Mid-Miocene normal faults and the basin-bounding master faults (e.g. VMF, H1).

Figure 4. (A) $\Delta z$ magnetic anomaly map (Kiss \& Gulyás, 2006) overlain by the distribution of various (sub)volcanic features. Note the dominance of intrusions in a NE-SW trending zone of the Polgár Trough. (B) Root-Mean-Square (RMS) amplitude map in $\pm 250 \mathrm{msec}$ interval of the base Pannonian horizon. Note the good coincidence between the highest RMS amplitude values and the distribution of intrusions (sills) in the Polgár Trough. The large volcanic fields are also displayed with high RMS amplitude south of the basin-bounding Hajdú Fault Zone (H1-H5).

Figure 5. The main geometrical characteristics and seismic properties of interpreted subvolcanicvolcanic features.

Figure 6. The interpreted seismic reflection profile of the Arbitrary line 2. The trace of this profile can be seen on the Fig. 1B and Fig. 4A. Key stratigraphic horizons and tectonic elements are also displayed. The legend of horizons and faults is in Fig. 3. Note the dominance of Mid-Miocene normal faults in the Polgár Trough. Note the presence of shallow-level, mainly layer-parallel and slightly saucer-shaped intrusions. One of the most impressive forced folds evolved above shallowly emplaced, slightly saucer-shaped sill (e.g. s13). The Tiv-6 borehole penetrated the hydrothermal mound (hm7) which is located above a terminating sill (s12). Note the other hydrothermal mound (hm8) close to a normal fault. The interference zone enhances a seismic disturbance area induced by shelf-slope progradations from different directions. Possible magma-flow emplacement structures (steps) are enlarged in case of s14 and s11 below the profile.

Figure 7. (A) Profile 1 of the compactional forced fold (ff1) above slightly saucer-shaped intrusion (s13). Note the geometry of overlying basinal facies units of the Lake Pannon. The trace of Profile 1 is located on the Fig. 7C and E maps. (B) The same inset flattened to the tf horizon. Note the thickness change between tf (top fold) and ps (paleosurface) horizons and their diverging geometry which is typical in case of compactional forced fold. (C) TWT thickness map based on the ps and tf horizons. Note the reduced thickness above the middle of s13 intrusion. (D) The model of compactional forced fold modified after Hansen and Cartwright (2006a). Based on the thickness change, the emplacement of intrusion (s13) occurred after the deposition of ps horizon in the earliest Late Miocene. Note the lack of onlaps above the intrusion. (E) TWT thickness map using the base shelf-slope and former paleosurface (ps) horizons. Reduced thickness can be seen in the middle of the Polgár Trough above slightly saucer-shaped intrusions (e.g. s13, s14). The legend of intrusions can be seen on Fig. 4A.

This article is protected by copyright. All rights reserved. 
Figure 8. The interpreted seismic reflection profile of the Arbitrary line 3. The trace of this profile can be seen on the Fig. 1B and Fig. 4A. Key stratigraphic horizons and tectonic elements are also displayed. The legend of horizons and faults is in Fig. 3. Note the chain of hydrothermal mounds (hm2-hm6) above the tips of Mid-Miocene splay faults. Thickness change due to compactional difference can be clearly seen above hydrothermal mounds. Note the dominance of eye-shaped geometry. Hydrothermal mounds have strong amplitude upper and lower boundary reflections and chaotic internal reflections. Onlaps of earliest Late Miocene sediments (11.6-9.78 Ma) onto hydrothermal mounds indicate the time of their development.

Figure 9. (A-B) NW-SE trending flow-emplacement structures (steps) of the sill23 and sill11on their RMS amplitude map. Based on the greater number of linear features and their branching geometry in north-west, the possible magma-flow direction was from south-east to north-west. Note the increase in the number of lobes and their elongated geometry in the north-west direction. The boundary of sill 11 has sinuous lava-flow like morphology. (C) The model of step development redrawn after Schofield (2009). Note the increasing offset and increasing number of magma lobes in the magma propagation direction. Profile 1 and Profile 3 reveals that the number of steps and their offsets are increased in the magma propagation direction in northern part of the sill 23 and sill 11. Profile 2 reveals only one step with small offset of the southern part of sill 23. Profile 4 reveals no visible steps but small scale undulations of the southern part of the sill 11 . The traces of profiles are going perpendicular to the possible magma flow direction and can be seen on Fig. 9A and B.

Figure 10. (A) Neural network facies analysis using well-log data (RHOZ: density, GR: gamma-ray and PE: photoelectric absorption) and the core sample description of the HGh-1 borehole. The crossplot of GR and PE clearly separates a facies unit characterized by the highest PE (4-6 b/e) and lowest GR values ( $<50 \mathrm{API})$ corresponding to penetrated hydrothermal mound (hm11). (B) Neural network facies analysis using the same logs on the Tiv-6 borehole. Hydrothermal mound (hm7) is defined by the lowest GR values ( $<30 \mathrm{API}$ ) on the cross-plot. Both hydrothermal mounds were also identified on seismic profiles (see on Figs 5B/13; 6).

Figure 11. Summary table of the main volcanic and tectonic events in the Carpathian-Pannonian Region modified and complemented after Harangi \& Lenkey (2007). The orange line in the Volcanic Events indicates the interval of the changed volcanic activity in the Polgár Volcanic Field (PVF). The nearby contemporaneous volcanic events were also added (e.g. Sárospatak, Mk-4 borehole). The dashed lines illustrate the uncertainty interval in the beginning or ending of a given volcanic event. Local deformation phases were also displayed. Stress fields were derived from fault-slip analysis (Petrik, 2016). Subsidence curve of the Polgár Trough was based on Petrik (2016). The change in deformation phases (D7 to D8) was contemporaneous with the accelerated sediment accumulation in the Polgár Trough and the emplacement of intrusions.

Figure 12. (A) The earliest Late Miocene volcano-tectonic map of the study area with the segmented Hajdú Fault Zone at the southern border of the Polgár Trough. Note the possible magma flow direction from south-east to north-west between segmented faults. (B) Late Mid-Miocene volcanotectonic model of the study area. Magma flow occurred south of the Hajdú Fault Zone generating volcanic activity in the Polgár Volcanic Field during the Middle Miocene. Continuous basin-bounding sinistral strike-slip fault prevented magma flow toward the basin centre. (C) Earliest Late Miocene volcano-tectonic model of the study area. Magma flow toward basin centre could have been facilitated by segmentation of the Hajdú Fault Zone. (A) and (C) indicate the same time interval in map-view and in 3D, respectively.

This article is protected by copyright. All rights reserved. 


\section{SUPPLEMENTARY MATERIAL (SM)}

SM1. Lithological columns of the key investigated boreholes. The most important fossils, magnetostratigraphic ages (Pogácsás et al., 1994) and maximum flooding surface (Magyar, 2010) are also displayed. Note the main suites (e.g. basinal, shelf-slope) of the Polgár Trough indicated with different colours.

SM2. Seismic velocity data obtained from check-shot data of Tikeszi-1 and sonic log data of Tiv-6 and Tit-1 wells plotted against the one-way travel time mid-point for relevant stratigraphic intervals. Note the abrupt velocity increase in the upper syn-rift succession where magmatic intrusions are seated.

SM3. Details of seismic resolution, detection limit and interval velocity. Details of magnetic $\Delta \mathrm{z}$ anomaly map.

SM4. Uninterpreted seismic profiles of Arbitrary line 1 and 2. See the profile traces on the Fig. 1B.

SM5. Uninterpreted seismic profile of the Arbitrary line 3. See the profile trace on the Fig. 1B.

SM6. Three-dimensional display of some intrusions identified by self-organising neural network analysis. Intrusions belonging to one well-defined class represented by high RMS, Envelope and Sweetness; even tenfold reflection intensity and amplitude contrast with respect to host rocks; and low iso-frequency component. Note the layer-parallel (e.g. s11) and slightly saucer-shaped sills (e.g. s14, s18). Small white arrows indicate the long linear features (e.g. flow-emplacement structures) in case of s14, s12 and s11.

SM7. Details of uncertainties in seismic interpretation.

This article is protected by copyright. All rights reserved. 


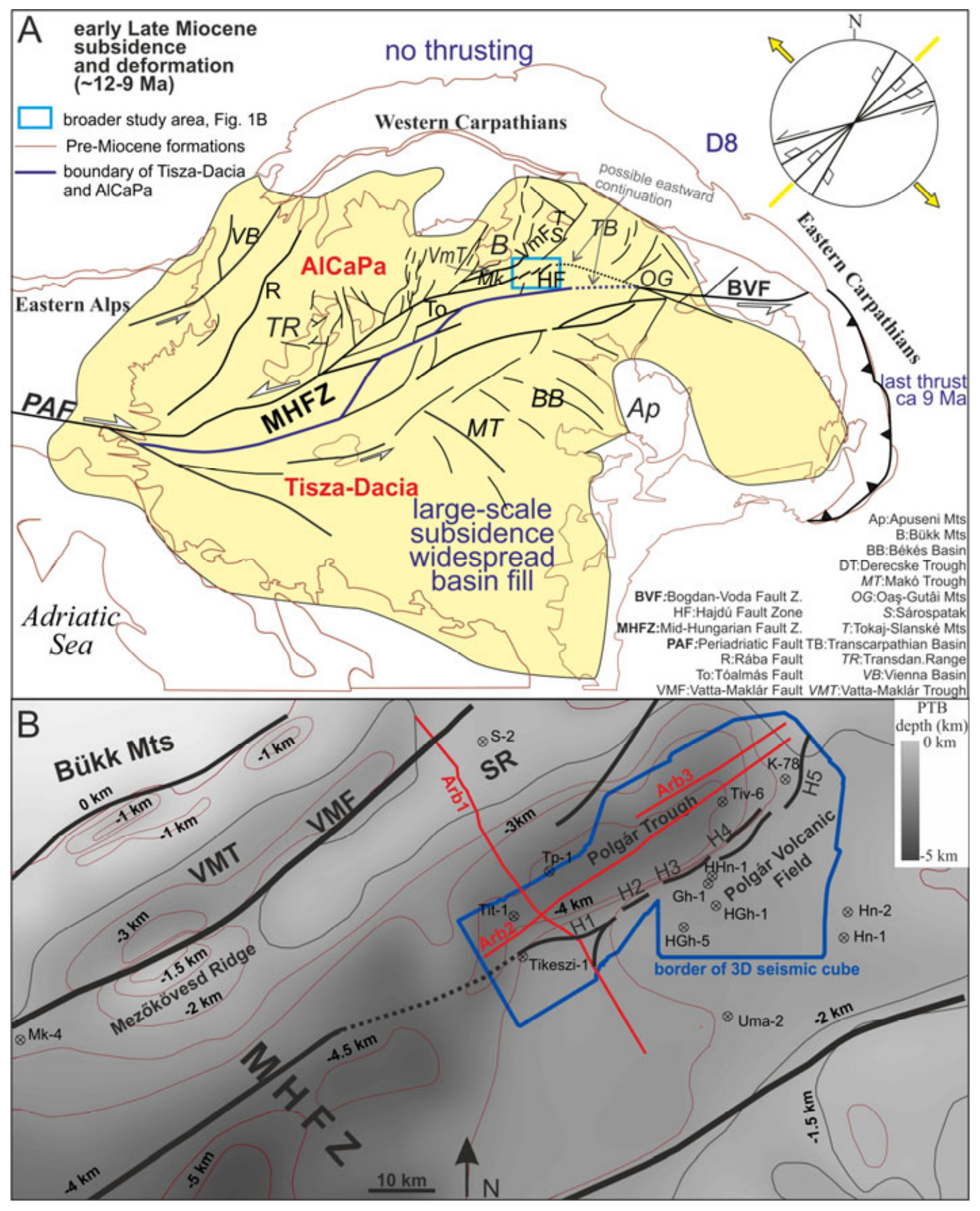

This article is protected by copyright. All rights reserved. 


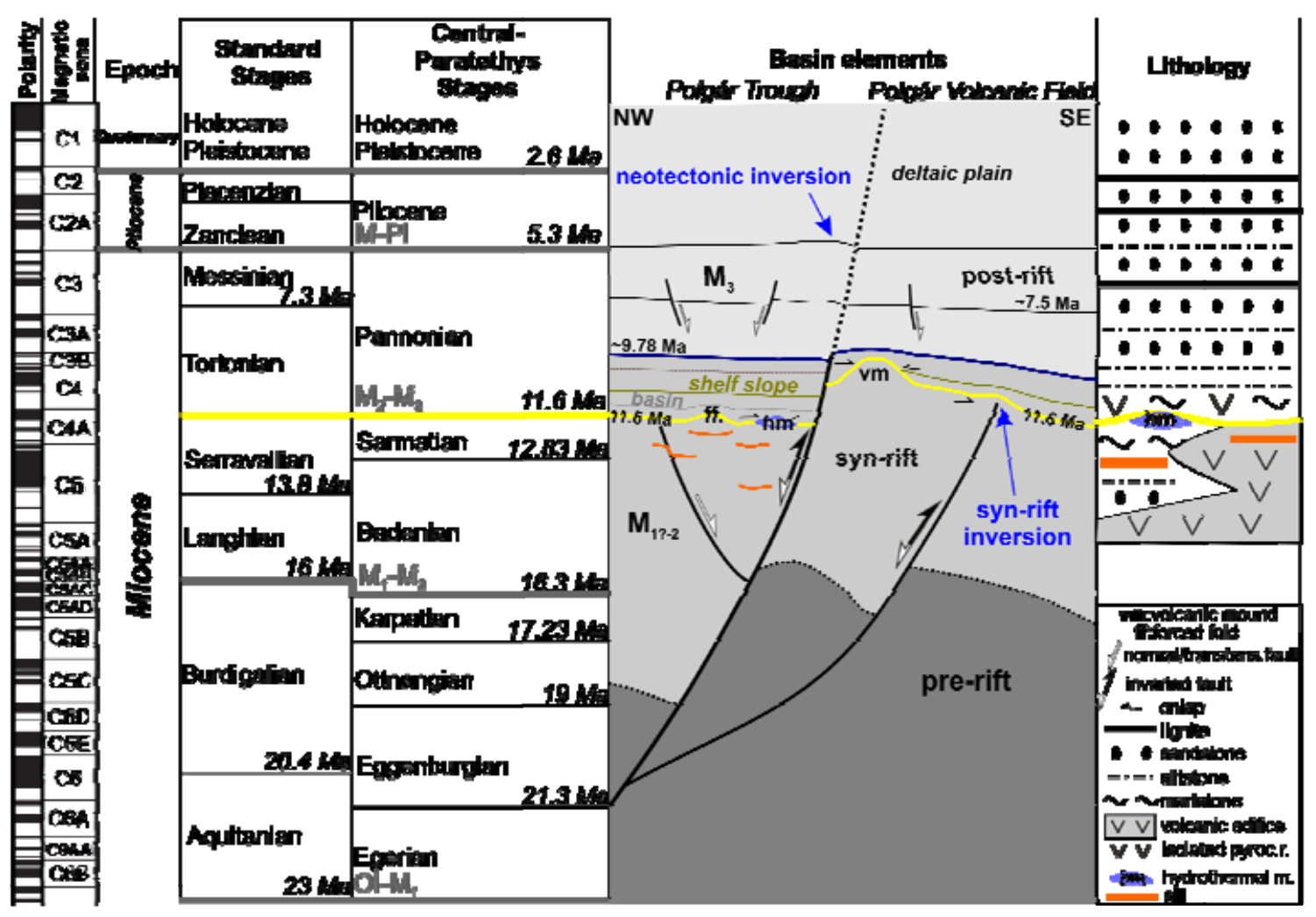




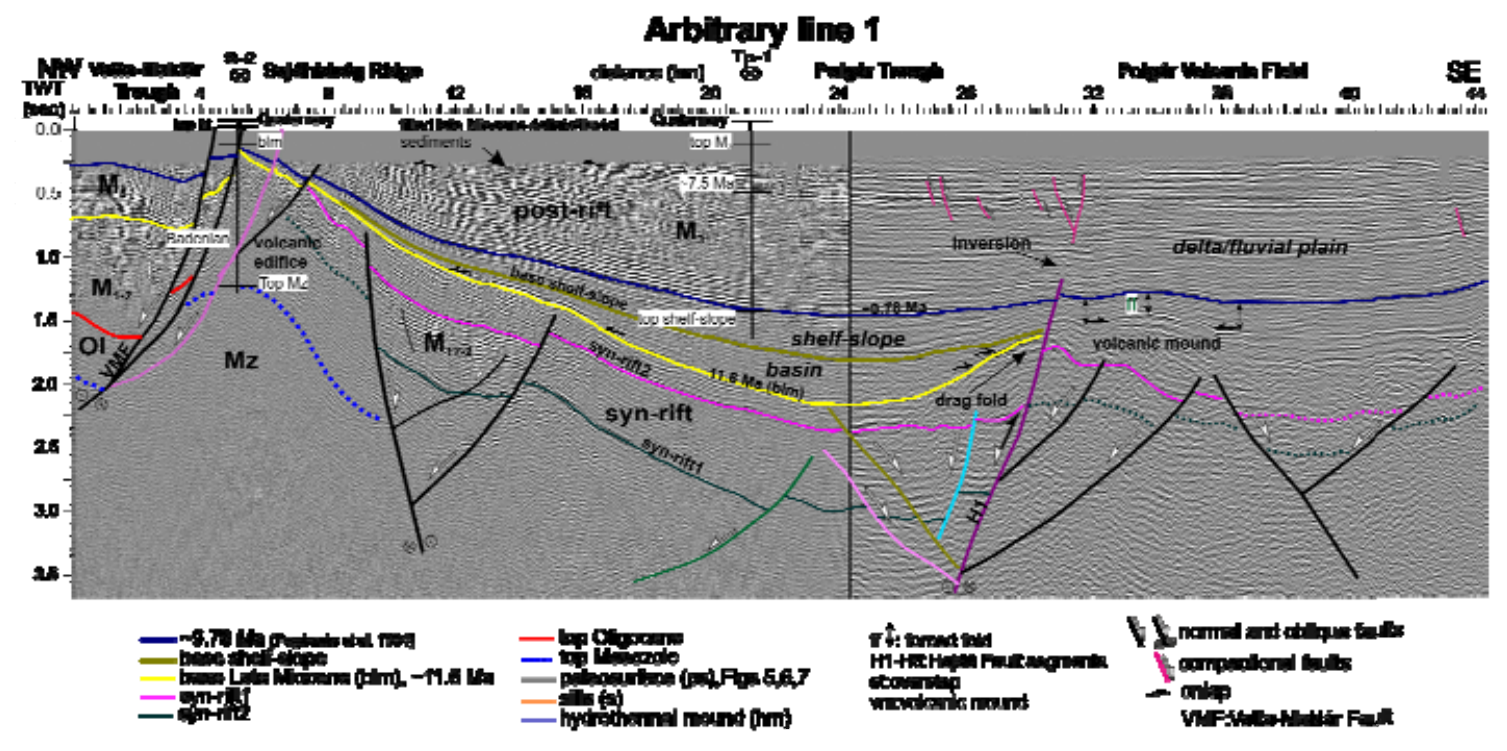




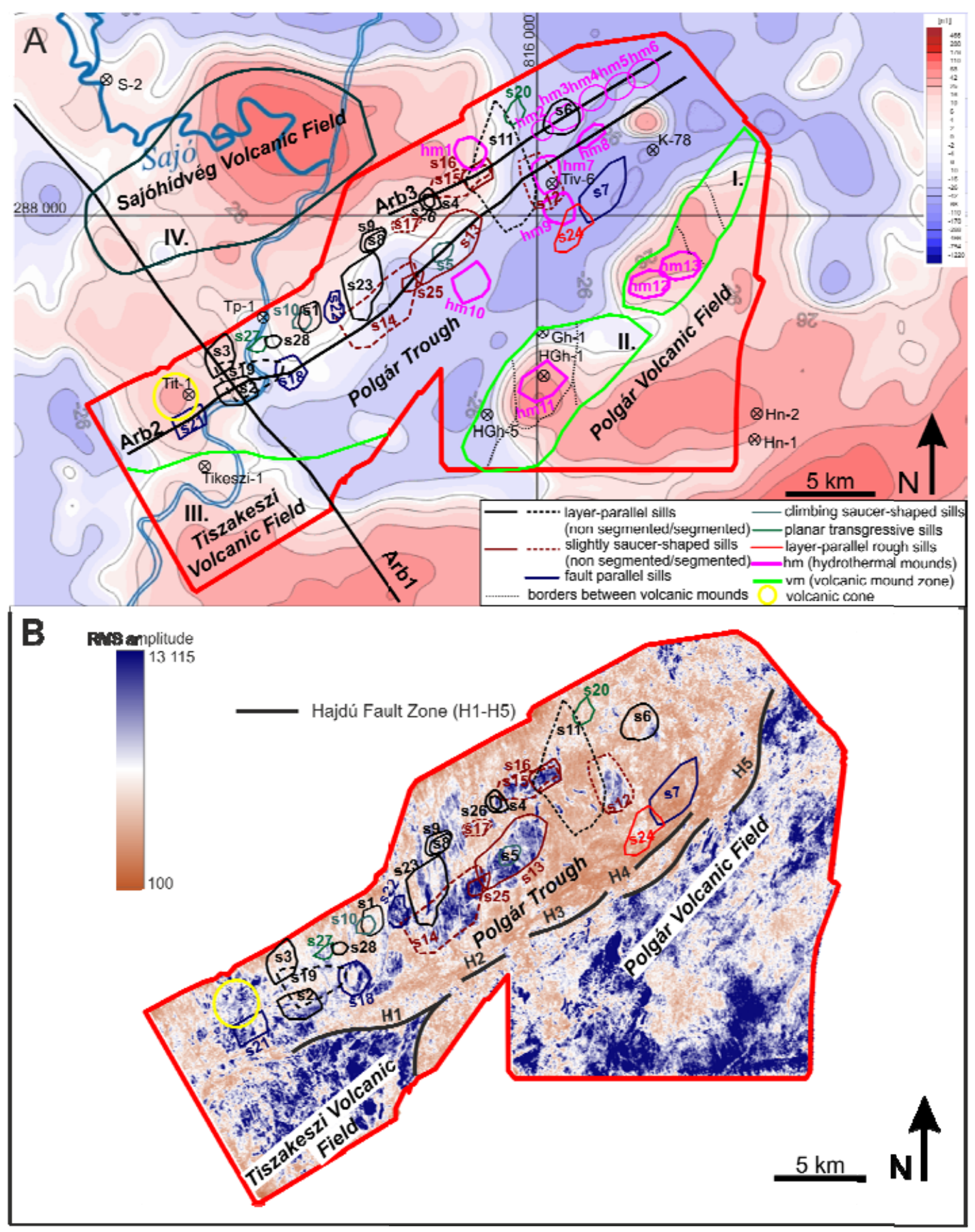



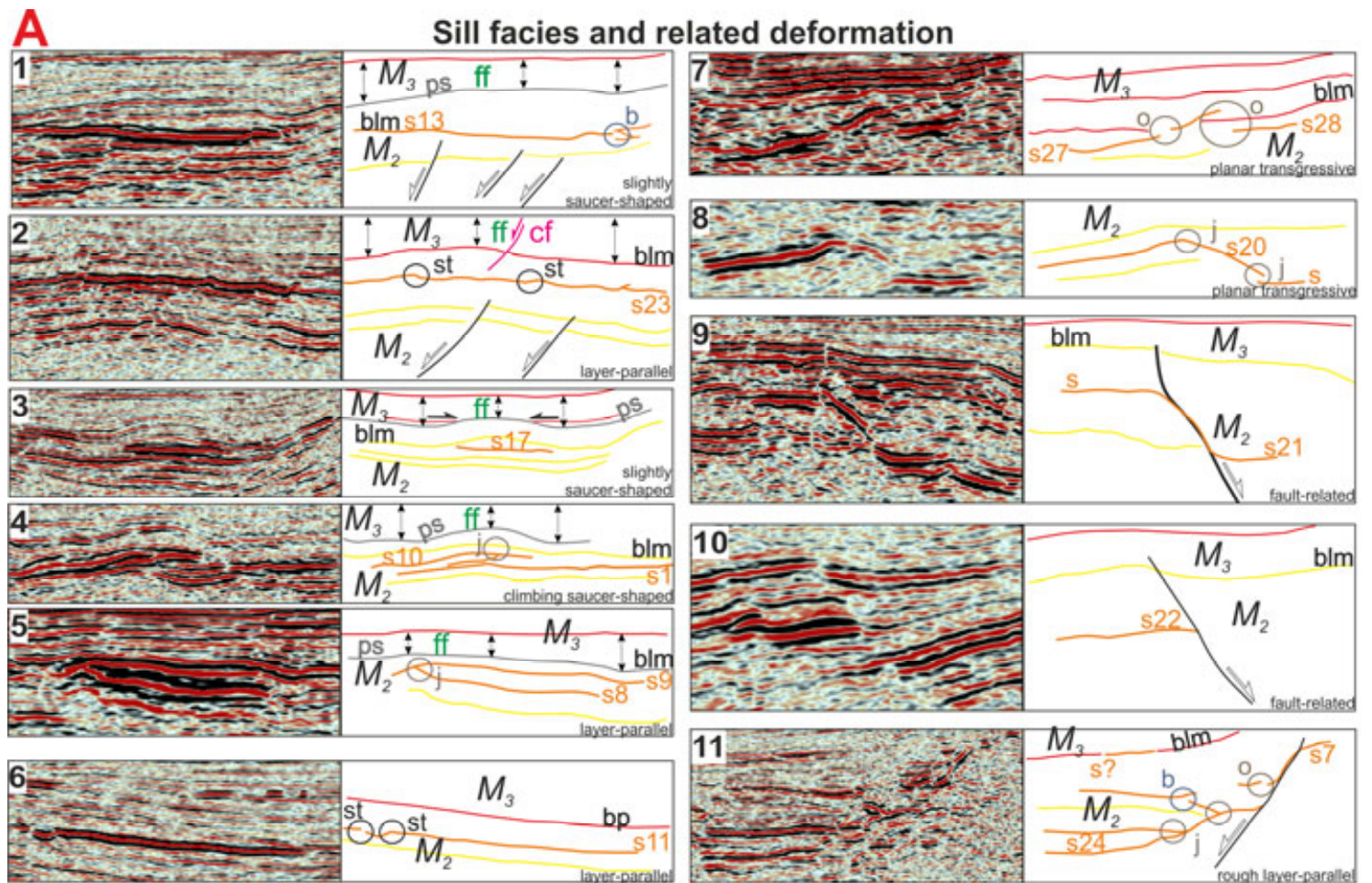

B

Hydrothermal mounds and related deformation
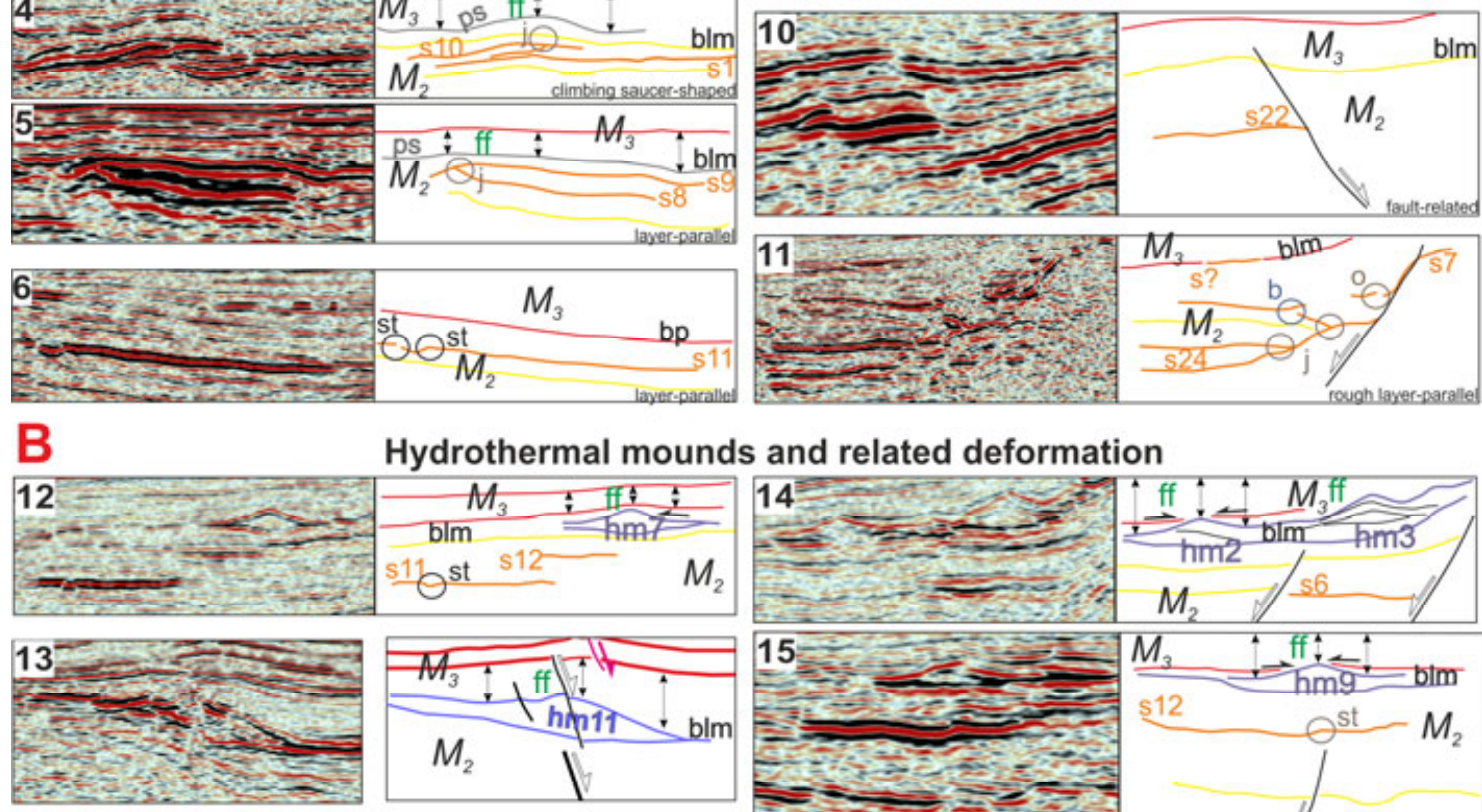

C

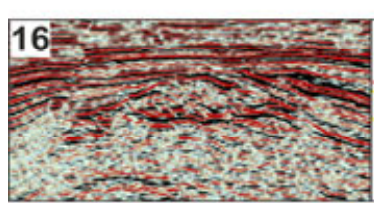

Volcanic mounds and related deformation

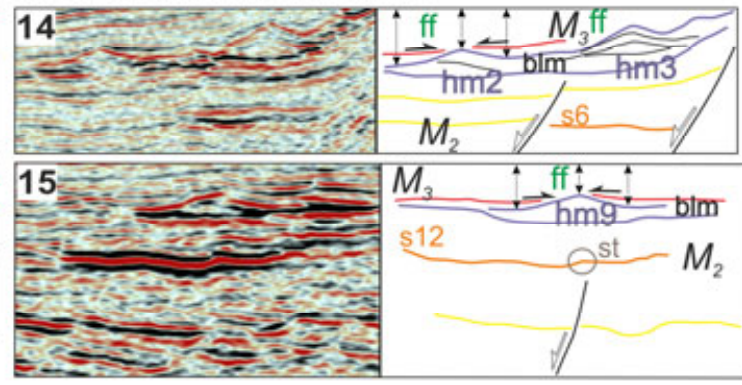

V $M$ J ff
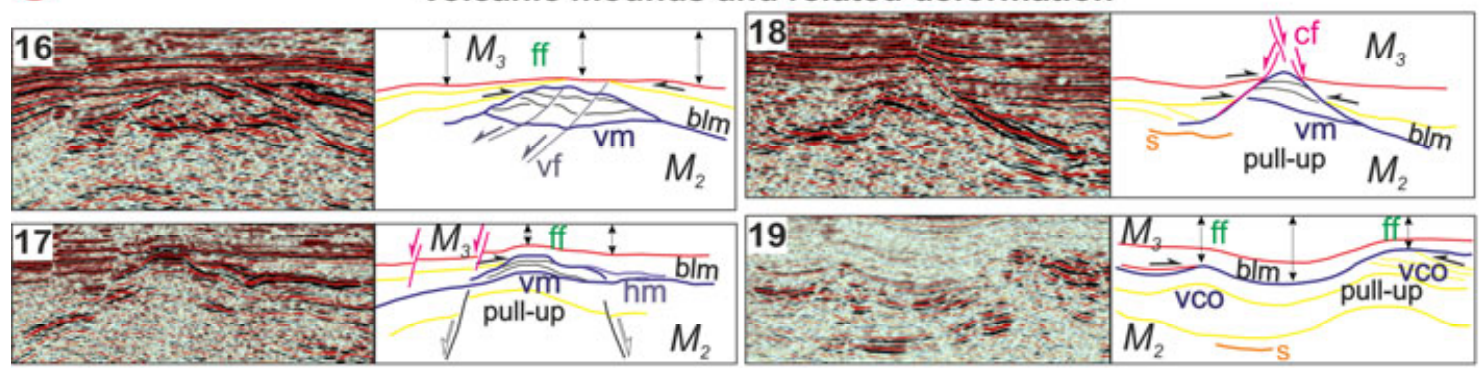

\section{Legend}

$\begin{array}{ll}\text { Ob: bridge (sills) } & \vdots \text { ff: forced fold } \\ \text { j: junction point (sills) } & \forall \text { cf: compactional fault } 1 \mathrm{~km} \\ \text { Oo: offset } & \quad \text { vf: volcanotectonic fault } \\ \text { Ost: overstep (sills) } & \quad / \text { fault } \rightarrow \text { onlap }\end{array}$

— hm:hydrothermal mound — vco: volcanic cone

— s:sill

— vm: volcanic mound lava/pyroclastic deposits

blm: base Late Miocene

— sedimentary deposits

- ps: palaeosurface

This article is protected by copyright. All rights reserved. 


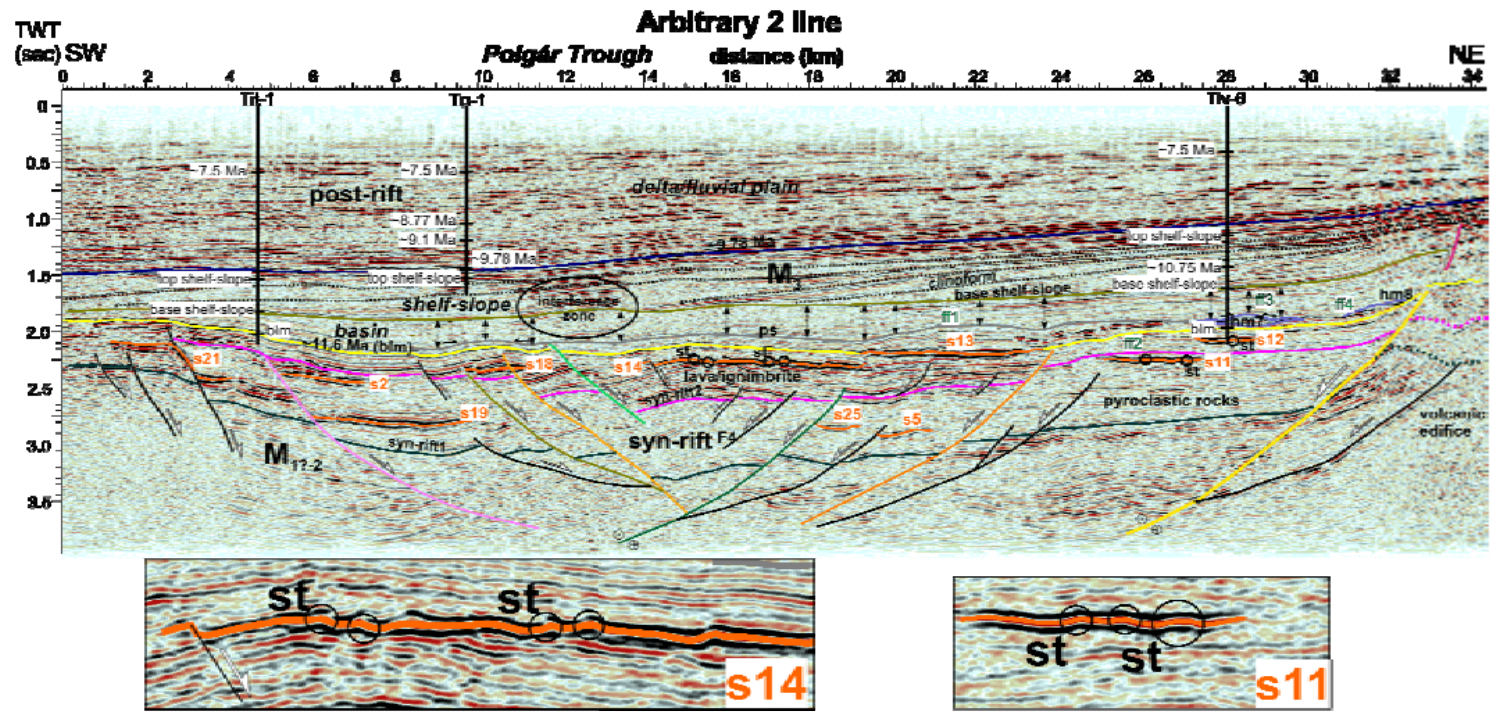




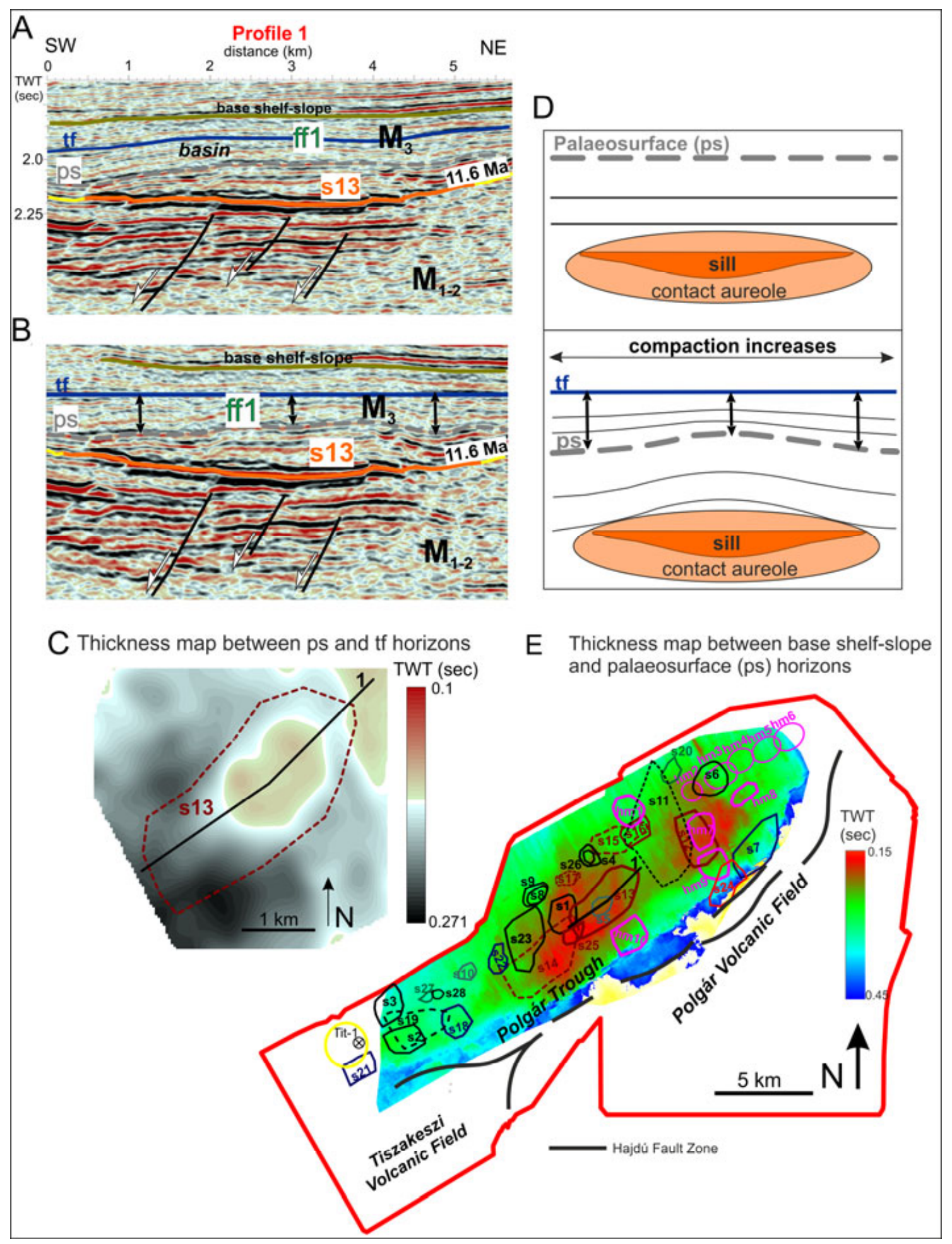

This article is protected by copyright. All rights reserved. 


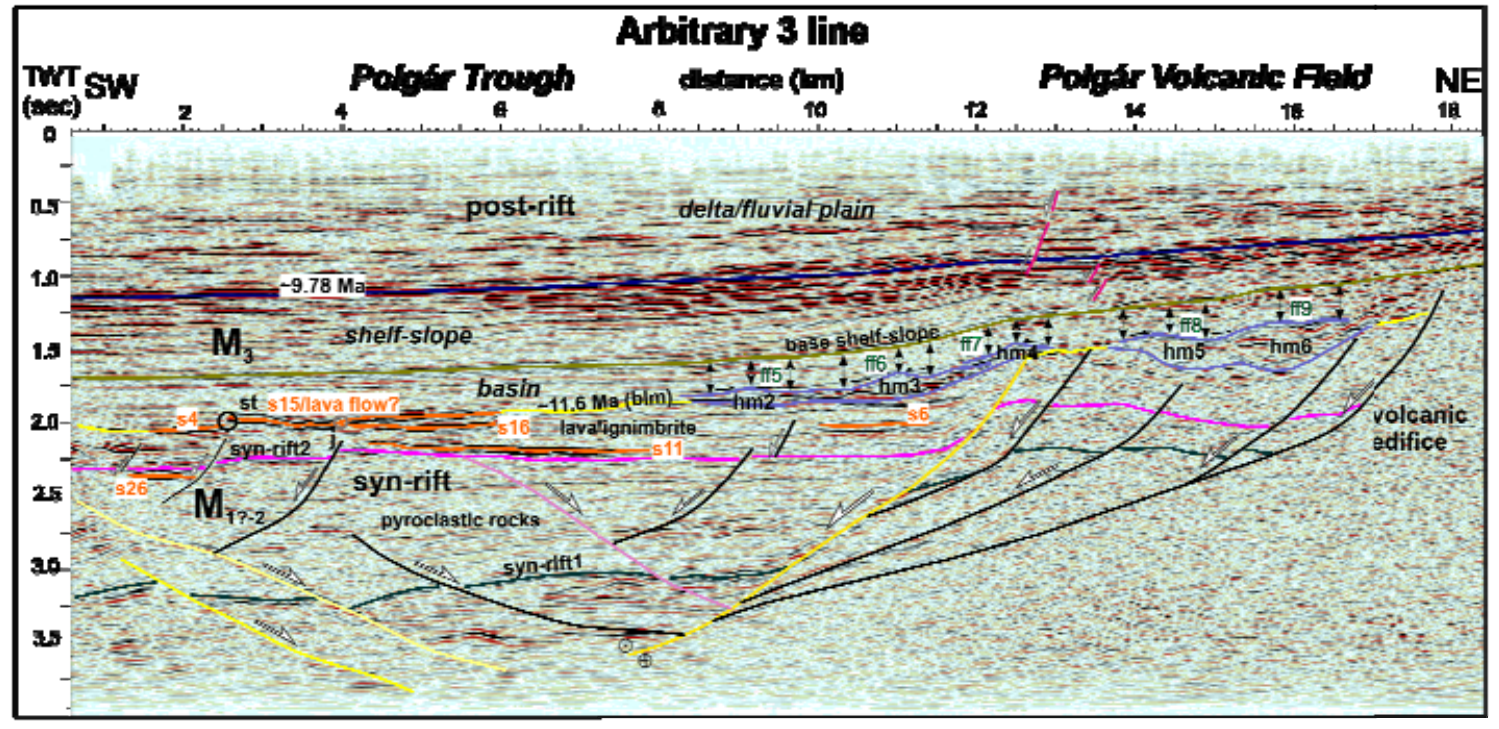




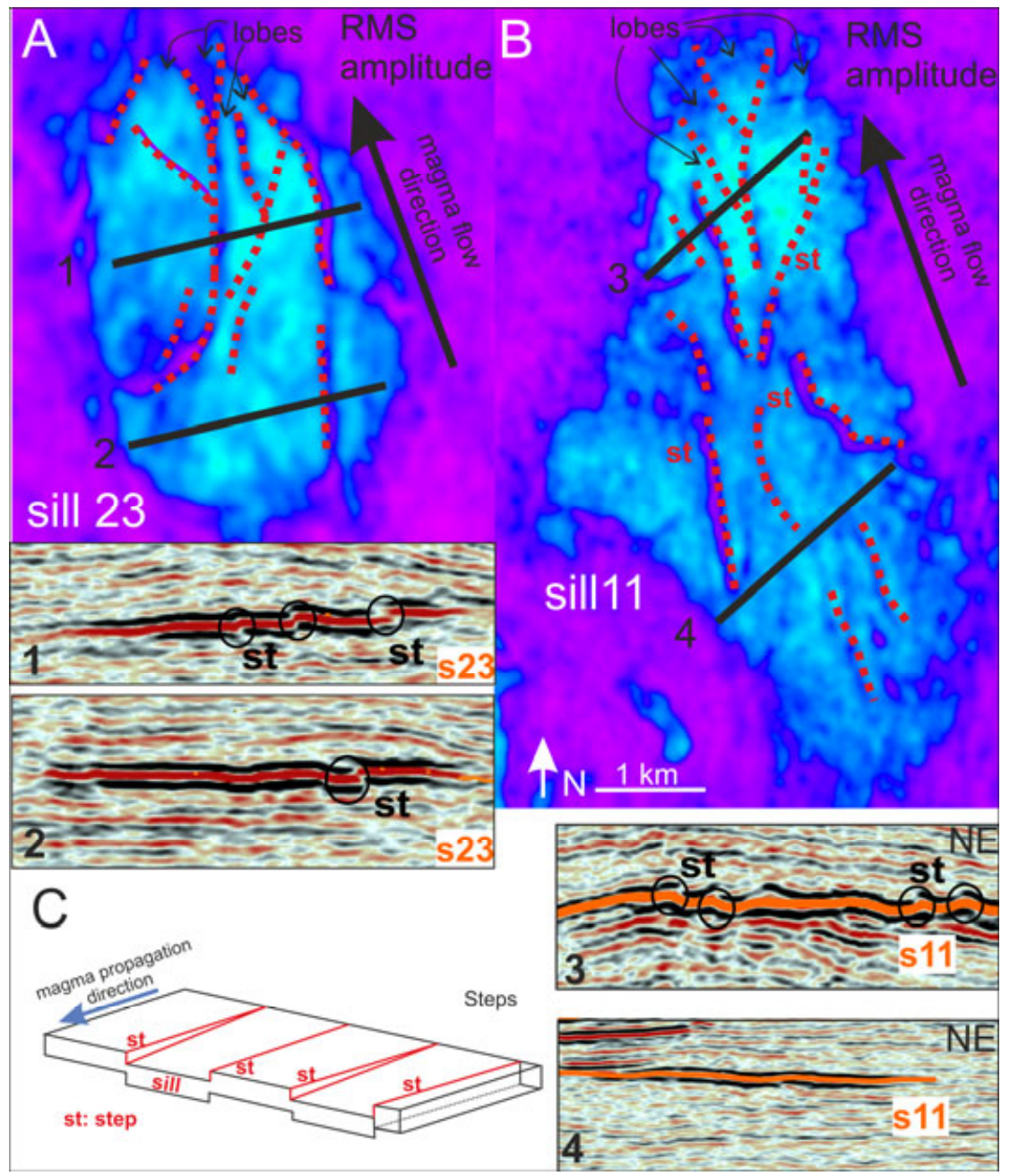

This article is protected by copyright. All rights reserved. 

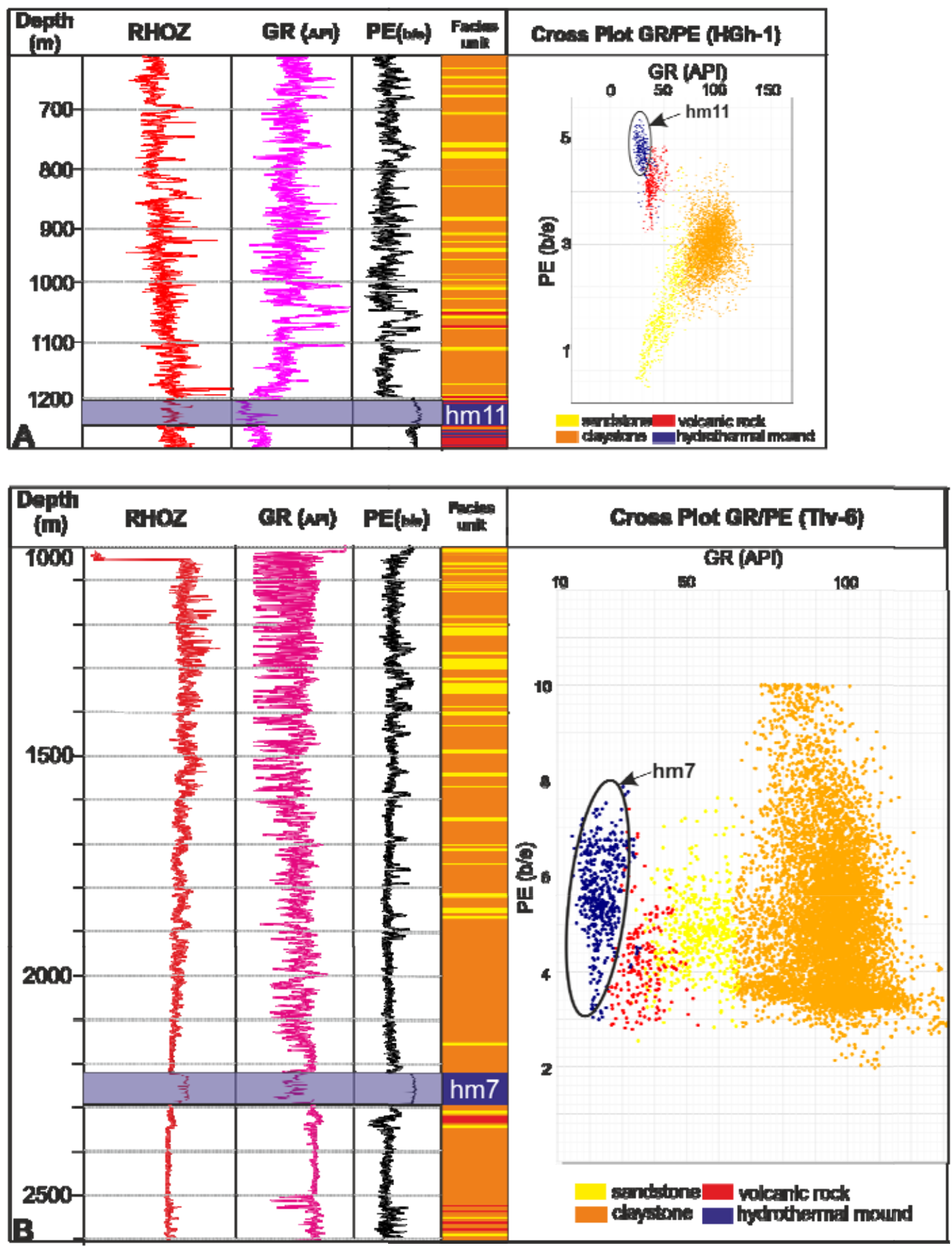


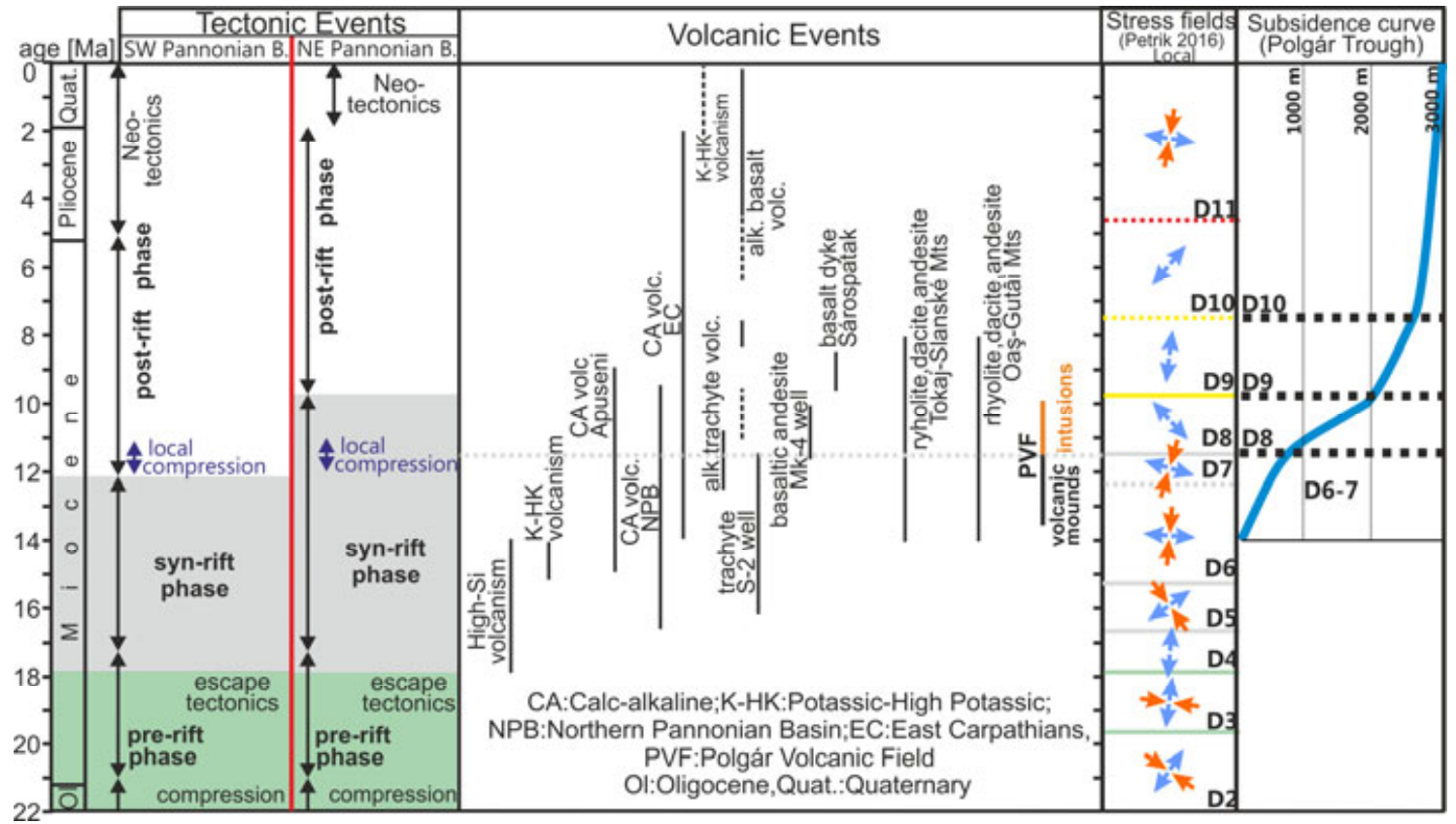

This article is protected by copyright. All rights reserved. 


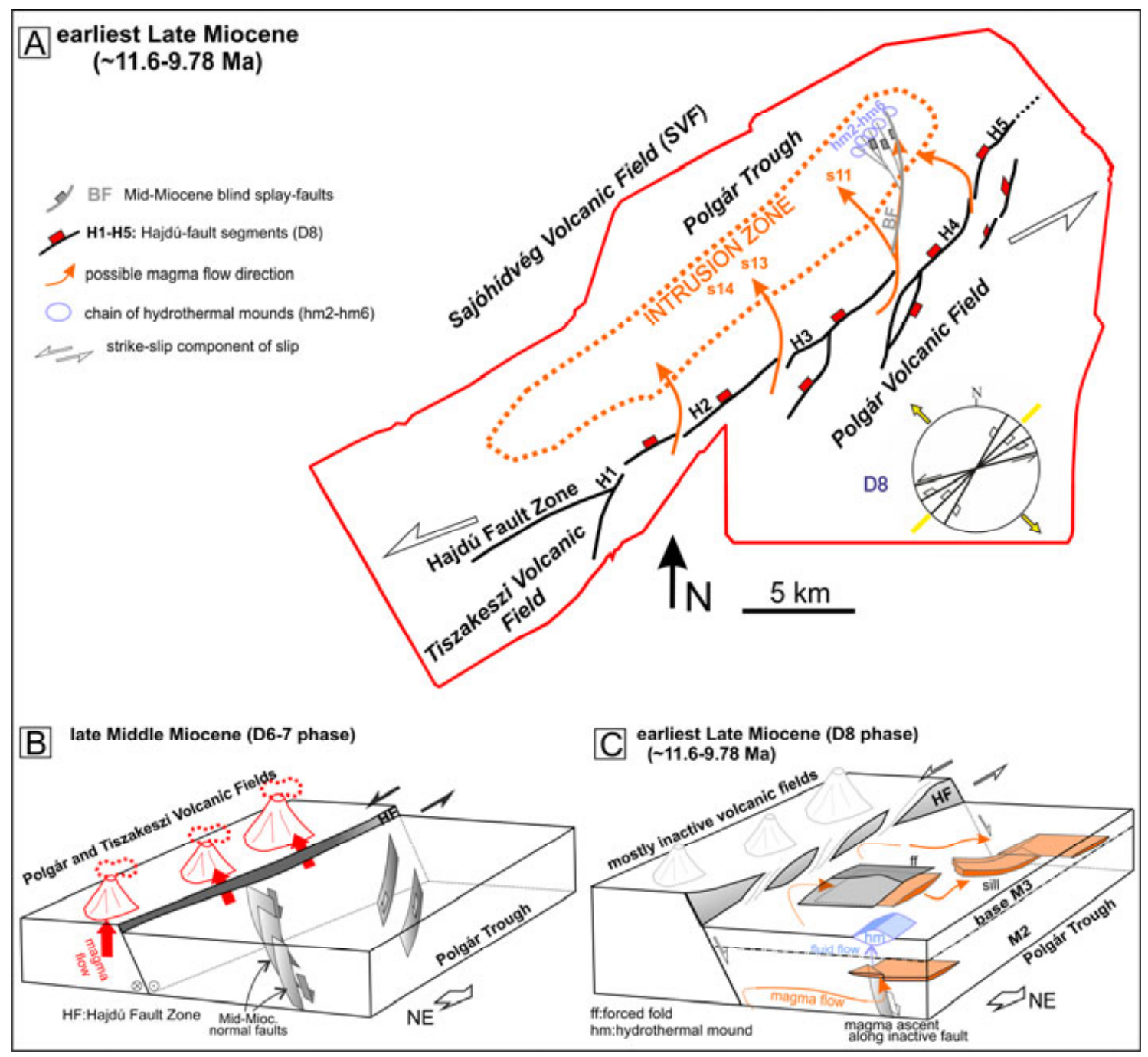

This article is protected by copyright. All rights reserved. 